\title{
Characterisation of GOME-2 formaldehyde retrieval sensitivity
}

\author{
W. Hewson ${ }^{1}$, H. Bösch ${ }^{1}$, M. P. Barkley ${ }^{1}$, and I. De Smedt ${ }^{2}$ \\ ${ }^{1}$ EOS Group, Department of Physics and Astronomy, University of Leicester, Leicester, UK \\ ${ }^{2}$ Belgian Institute for Space Aeronomy (BIRA-IASB), Avenue Circulaire, 3, 1180, Brussels, Belgium \\ Correspondence to: W. Hewson (wh18@le.ac.uk)
}

Received: 30 August 2012 - Published in Atmos. Meas. Tech. Discuss.: 24 September 2012

Revised: 10 January 2013 - Accepted: 25 January 2013 - Published: 18 February 2013

\begin{abstract}
Formaldehyde $\left(\mathrm{CH}_{2} \mathrm{O}\right)$ is an important tracer of tropospheric photochemistry, whose slant column abundance can be retrieved from satellite measurements of solar backscattered UV radiation, using differential absorption retrieval techniques. In this work a spectral fitting sensitivity analysis is conducted on $\mathrm{CH}_{2} \mathrm{O}$ slant columns retrieved from the Global Ozone Monitoring Experiment 2 (GOME-2) instrument. Despite quite different spectral fitting approaches, the retrieved $\mathrm{CH}_{2} \mathrm{O}$ slant columns have geographic distributions that generally match expected $\mathrm{CH}_{2} \mathrm{O}$ sources, though the slant column magnitudes and corresponding uncertainties are particularly sensitive to the retrieval set-up. The choice of spectral fitting window, polynomial order, $\mathrm{I}_{0}$ correction, and inclusion of minor absorbers tend to result in the largest modulations of retrieved slant column magnitude and fit quality. However, application of a reference sector correction using observations over the remote Pacific Ocean is shown to largely homogenise the resulting $\mathrm{CH}_{2} \mathrm{O}$ vertical columns obtained with different retrieval settings, thereby largely reducing any systematic error sources from spectral fitting.
\end{abstract}

\section{Introduction}

Formaldehyde $\left(\mathrm{CH}_{2} \mathrm{O}\right)$ is an important atmospheric trace gas found throughout the troposphere, produced from the oxidation of volatile organic compounds. Methane oxidation is by far the biggest source of $\mathrm{CH}_{2} \mathrm{O}$, sustaining global background levels of $0.25-0.75 \times 10^{16}$ molecules $\mathrm{cm}^{-2}$ (Stavrakou et al., 2009a; Boeke et al., 2011). However, over continental regions large $\mathrm{CH}_{2} \mathrm{O}$ enhancements often occur near localised VOC sources, readily observable by both airborne and ground based measurement campaigns (e.g. Fried et al., 2008; MacDonald et al., 2012). $\mathrm{CH}_{2} \mathrm{O}$ is also directly released or produced from biomass burning and industrial processes (Yokelson, 1999; Parrish et al., 2012); direct $\mathrm{CH}_{2} \mathrm{O}$ emissions from vegetation are a minor source (Rottenberger et al., 2004). $\mathrm{CH}_{2} \mathrm{O}$ has a short atmospheric lifetime of only a few hours, with atmospheric sinks primarily determined by photolysis and reaction rates against the hydroxyl radical (OH) (Cooke et al., 2010). Consequently, determination of $\mathrm{CH}_{2} \mathrm{O}$ magnitudes and distributions are of major importance in interpreting the $\mathrm{OH}$ chain, particularly for highly reactive tropical ecosystems (Singh et al., 1995). The molecule's rapid reaction time makes it a suitable proxy for detecting active photochemistry and determining surface VOC emissions (e.g. Palmer et al., 2003; Barkley et al., 2009; Stavrakou et al., 2009a; Curci et al., 2010; De Smedt et al., 2010; Boeke et al., 2011; Gonzi et al., 2011). In particular, many studies have used satellite $\mathrm{CH}_{2} \mathrm{O}$ column observations to infer top-down emissions estimates of isoprene, which is the dominant biogenic VOC emitted from terrestrial vegetation (see Abbot et al., 2003; Palmer et al., 2003, 2006; Shim et al., 2005; Millet et al., 2006, 2008; Fu et al., 2007; Barkley et al., 2008; Stavrakou et al., 2009b; Marais et al., 2012).

Despite $\mathrm{CH}_{2} \mathrm{O}$ 's high atmospheric abundance, its detection remains inherently difficult due to its extremely weak absorption signature. Nevertheless, space-borne monitoring of $\mathrm{CH}_{2} \mathrm{O}$ was first realised with the launch of the Global Ozone Monitoring Experiment (GOME) in 1995 (Burrows et al., 1999), with Thomas et al. (1998) publishing the first $\mathrm{CH}_{2} \mathrm{O}$ observations of a biomass burning event over Indonesia in 1997. Later work with the GOME dataset by Chance et al. (2000) incorporated major advances in the detection of minor absorbers, reducing fitting residuals on the $\mathrm{CH}_{2} \mathrm{O}$ slant column fit to around $5 \times 10^{-4}$, with fitting precision of $<0.4 \times 10^{16}$ molecules $\mathrm{cm}^{-2}$. Further retrievals by Wittrock 
(2006) and De Smedt et al. (2008), using spectral measurements from SCIAMACHY on-board ENVISAT, retrieved $\mathrm{CH}_{2} \mathrm{O}$ to a precision of about $1.0 \times 10^{16}$ molecules $\mathrm{cm}^{-2}$ for a single observation. The larger fitting uncertainty of SCIAMACHY, compared with GOME, is attributed to its finer spatial resolution, resulting in a reduced signal to noise ratio (De Smedt et al., 2008). $\mathrm{CH}_{2} \mathrm{O}$ columns have also been observed from Ozone Monitoring Instrument (OMI), a CCD spectrometer aboard NASA's Aura satellite (launched 2004), through a non-linear direct fitting of radiances developed by Chance (2002) and Kurosu et al. (2004); reported OMI slant column uncertainties are about 40-100\%. GOME-2, the successor to the original GOME mission, was launched in October 2006, with the initial retrievals of De Smedt et al. (2009, 2012) and Vrekoussis et al. (2010) yielding fitting precisions of $\sim 0.8 \times 10^{16}$ molecules $\mathrm{cm}^{-2}$, and spatial distributions consistent with previous sensors.

However, despite a heritage of $\mathrm{CH}_{2} \mathrm{O}$ monitoring from space, the $\mathrm{CH}_{2} \mathrm{O}$ column retrievals still remain less well characterised when compared to major absorbers such as ozone (e.g. Van Roozendael et al., 2002; Balis et al., 2008; Loyola et al., 2011b) and nitrogen dioxide (e.g. Boersma et al., 2004; Richter et al., 2011; Valks et al., 2011). This work attempts to address this issue by presenting a detailed assessment and characterisation of GOME- $2 \mathrm{CH}_{2} \mathrm{O}$ retrieval uncertainties. Increased accuracy of the $\mathrm{CH}_{2} \mathrm{O}$ column product improves confidence in its use for constraining surface emissions.

\section{Instrument and retrieval methods}

The GOME-2 UV spectrometer is mounted on board EUMETSAT's MetOp-A spacecraft. Operating in a sun synchronous near-polar orbit, the satellite orbits the Earth every $101 \mathrm{~min}$, with a local Equator crossing time of 09:30. GOME-2 samples the $240-790 \mathrm{~nm}$ spectral range with a spectral resolution between $0.24-0.5 \mathrm{~nm}$, and a typical spatial resolution of $80 \times 40 \mathrm{~km}^{2}$. GOME-2 minor absorber products are retrieved operationally by the GOME Data Processor using the standard differential optical absorption spectroscopy (DOAS) method (Loyola et al., 2011a). For $\mathrm{CH}_{2} \mathrm{O}$, this involves fitting trace gas absorption cross sections to measured atmospheric absorption spectra, retrieving the $\mathrm{CH}_{2} \mathrm{O}$ slant column abundance along the instrument's viewing geometry. Slant columns are then converted to vertical columns, after division by an air mass factor computed using a radiative transfer model based on assumed or known atmospheric and surface properties (Palmer et al., 2001; Martin et al., 2002).

In the analyses that follow, a default reference retrieval described in Table 1 is adjusted one setting at a time to determine the sensitivity of the DOAS retrieval within a range of optimised settings. Sensitivity is analysed with reference to the retrieved $\mathrm{CH}_{2} \mathrm{O}$ column, $1 \sigma$ standard deviation of the $\mathrm{CH}_{2} \mathrm{O}$ column, and reduced $\chi^{2}$. We use the $\chi^{2}$ statistic as a
Table 1. Default retrieval settings used in the sensitivity analysis, based on De Smedt (2011). Differences to the original retrieval are the inclusion of an undersampling cross section, and exclusion of an $\mathrm{OClO}$ fit.

\begin{tabular}{ll}
\hline Parameter & Setting \\
\hline Fit window & BrO 328.5-359 nm (Theys, 2010) \\
& $\mathrm{CH}_{2} \mathrm{O} 328.5-346 \mathrm{~nm}$ (De Smedt, 2011) \\
Polynomial & 5th order \\
Cross sections & $\mathrm{BrO}(223 \mathrm{~K})($ Fleischmann et al., 2004) \\
& $\mathrm{CH}_{2} \mathrm{O}(298 \mathrm{~K})$ (Meller and Moortgat, 2000) \\
& $\mathrm{NO}_{2}(220 \mathrm{~K})($ Vandaele et al., 1998) \\
& $\mathrm{O}_{3}(228$ and 243 K) (Malicet et al., 1995) \\
& $\left(\mathrm{I}_{0}\right.$ corrected using 0.8 $\left.\times 10^{19}\right)$ \\
Linear offset & 1st order \\
Ring & Vountas et al. (1998), Rozanov et al. (2005) \\
Undersampling & Chance et al. (2005) \\
Scan bias & Eta and zeta polarisation vectors \\
& (EUMETSAT, 2011) \\
Slit function & Siddans et al. (2006) \\
Solar reference & GOME-2 daily solar mean reference \\
$\mathrm{I}_{0}$ calibration & Caspar and Chance (1997) \\
\hline
\end{tabular}

measure of the goodness of fit for retrievals, with $\chi^{2}$ reducing towards a minimum limit of estimated noise as fit quality increases. This is output directly from QDOAS following Eq. (5) in Fayt et al. (2011):

$\chi^{2}\left(a_{i}\right)=\frac{\left(y\left(a_{i}\right)-y\right) \times\left(y\left(a_{i}\right)-y\right)}{M-N}$,

where $\chi^{2}$ is calculated as the difference between our observations $(y)$ and the function $y\left(a_{i}\right)$ representing our model of the observation, $a_{i}$ representing each parameter $N$, and $M-N$ accounting for the degrees of freedom allowed in the fit. This has the advantage over a basic analysis of fitting residuals in that any extra degrees of freedom allowed by the inclusion of extra fitting parameters are accounted for.

The chosen reference retrieval settings are largely based on the initial GOME-2 $\mathrm{CH}_{2} \mathrm{O}$ characterisation of De Smedt (2011). By analysing the ensuing parameters with respect to the reference retrieval, differences in slant columns are attributed to systematic effects imparted by each parameter adjustment. The random error component of the retrieval (or the noise in GOME-2 measured Earthshine spectra) is reduced by analysing a monthly mean rather than individual orbits.

The DOAS retrieval itself is performed using the QDOAS analysis software (Fayt et al., 2011), prior to which trace gas cross sections listed in Table 1 are corrected to vacuum wavelengths (where appropriate), and convolved with the GOME2 slit function measured pre-launch (Siddans et al., 2006), using the daily Solar Mean Reference (SMR) wavelength grid taken from the relevant L1B orbit file. Ozone cross sections are corrected for the $\mathrm{I}_{0}$ effect (Aliwell et al., 2002). Shift and stretch parameters are applied to Earthshine spectra, accounting for a very small error contribution from Doppler 


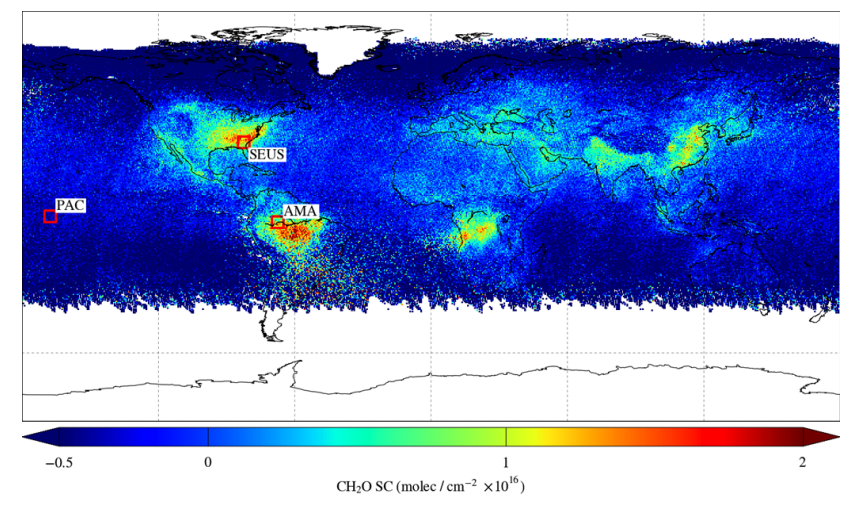

Fig. 1. Monthly mean $\mathrm{CH}_{2} \mathrm{O}$ slant columns for August 2007 retrieved using the default algorithm settings (Table 1). The data are averaged onto a $0.5^{\circ} \times 0.5^{\circ}$ grid excluding observations with cloud fraction $>0.4$ and solar zenith angles $>60^{\circ}$.

shift due to spacecraft and planetary motion. An improved wavelength calibration for the GOME- 2 SMR $\mathrm{I}_{0}$ reference is employed to further increase the accuracy of wavelength to pixel mapping in order to further reduce fit residuals arising from mis-alignment of Earthshine and SMR spectra (Caspar and Chance, 1997; Van Geffen and Van Oss, 2003). Postprocessing is initially limited to discarding observations with cloud fraction greater than 0.4 and solar zenith angles (SZA) of $60^{\circ}$. Monthly mean $\mathrm{CH}_{2} \mathrm{O}$ slant columns for August 2007, generated with this reference retrieval, are shown in Fig. 1. A sample DOAS fit for a region of enhanced isoprene emissions over the southeast US (see Palmer et al., 2003) is presented in Fig. 2.

Global results are complemented by a detailed analysis for three $5^{\circ} \times 5^{\circ}$ sub-regions (detailed in Fig. 1) to examine regional effects potentially masked in the global statistics. The sites chosen reflect the range of $\mathrm{CH}_{2} \mathrm{O}$ column concentrations expected to be retrieved: (1) the remote Pacific (PAC) providing a clean reference in which only background concentrations of $\mathrm{CH}_{2} \mathrm{O}$ are expected, (2) the southeast United States (SEUS) at the height of the regional growing season, and (3) a portion of the Amazon rainforest (AMA) where large $\mathrm{CH}_{2} \mathrm{O}$ enhancements due to high biogenic emissions occur (Barkley et al., 2008). Results for all sites are given as means over their respective geographic area.

\section{DOAS parameter sensitivities}

Sensitivity test results are presented in Table 2, to which the reader is referred by test numbers in-line and their corresponding descriptions. The sensitivity tests are divided into three groups: (1) spectral fit range, (2) spectral fit approaches, and (3) instrumental corrections. Following this, effects due to post-processing of slant columns are discussed in Sect. 4. Analysis of each setting accompanies the description of its influence on the retrieval.

\subsection{Spectral fit range}

Selection of an appropriate fitting window is known to be a major component of achieving an accurate DOAS fit, particularly for weak absorbers (Aliwell et al., 2002). Fit problems are prone to arise when different trace gas absorption features overlap, with weakly absorbing spectra $\left(\mathrm{CH}_{2} \mathrm{O}\right.$, $\mathrm{BrO})$ masked by stronger absorbers $\left(\mathrm{O}_{3}\right.$, Ring). $\mathrm{CH}_{2} \mathrm{O}$ is typically retrieved in the lower end of the UV between 325 and $360 \mathrm{~nm}$ (Wittrock et al., 2000; De Smedt et al., 2008). A large degree of overlap between absorption cross sections is evident in this region, therefore the choice of fitting window immediately presents two problems which must be overcome to effect a reliable $\mathrm{CH}_{2} \mathrm{O}$ retrieval: (1) accurate retrieval of $\mathrm{O}_{3}$ in the lower reaches of the fitting window, and (2) reduction of a false detection relationship between $\mathrm{BrO}$ and $\mathrm{CH}_{2} \mathrm{O}$. Here, a selection of fit windows relevant to the GOME-2 fitting range, and used throughout the literature, are tested.

\subsubsection{BrO pre-fit}

The pre-fitting technique has been used in GOME-1 and GOME-2 retrievals (Chance et al., 2000; De Smedt et al., 2012) to counter the effect of spectral similarities between $\mathrm{BrO}$ and $\mathrm{CH}_{2} \mathrm{O}$. In the default test presented here, $\mathrm{BrO}$ is retrieved in a wide wavelength window $(328.5-359 \mathrm{~nm})$, using the same settings and spectra as found in the regular $\mathrm{CH}_{2} \mathrm{O}$ fit, with the exception of including scan bias correction spectra (EUMETSAT, 2011). Inclusion of these correction terms in both $\mathrm{BrO}$ and $\mathrm{CH}_{2} \mathrm{O}$ fit windows shows no discernible difference compared to scan correction in the $\mathrm{BrO}$ window alone, therefore in order to reduce the number of fitted parameters, corrections are applied to the $\mathrm{BrO}$ window only.

Based on the GOME-2 $\mathrm{BrO}$ retrievals as implemented in Theys et al. (2011), a slightly narrower $\mathrm{BrO}$ fit window is tested here in the $332-359 \mathrm{~nm}$ region, both with and without inclusion of the additional absorber $\mathrm{OClO}$ (as implemented in the retrieval of Theys et al., 2011). In the first instance, test 1a adjusts the $\mathrm{BrO}$ fit window alone to give a global $\mathrm{CH}_{2} \mathrm{O}$ slant column mean increase of $0.06 \times 10^{16}$ molecules $\mathrm{cm}^{-2}$, largely reflecting the increase over oceans of the same value, with a very small reducing effect on fit $\chi^{2}$. Including $\mathrm{OClO}$ in test $1 \mathrm{~b}$ increases $\mathrm{CH}_{2} \mathrm{O}$ slant column means further $\left(+0.15 \times 10^{16}\right.$ molecules $\left.\mathrm{cm}^{-2}\right)$ globally, with AMA showing a more pronounced increase than for 1a, although less so than the SEUS and PAC regions. Inclusion of OClO in both $\mathrm{BrO}$ and $\mathrm{CH}_{2} \mathrm{O}$ fit windows is tested further on in the study, but it should be noted that fit quality exhibits a tendency to increase in parallel with additional fitting parameters. In the case of including $\mathrm{OClO}$ here, whereby distributions of the additional absorber should be expected only on regional scales at high latitudes during the polar springtime (Kühl et al., 2006), fit quality is increased, but in an erroneous fashion. 
Table 2. Parameter effects on mean $\mathrm{CH}_{2} \mathrm{O}$ slant columns, \pm 1 standard deviation, and mean $\chi^{2}$ over the entire globe, Amazon, southeast US, and remote Pacific Ocean regions (as defined in Fig. 1). Slant column units are $\times 10^{16}$ molecules cm ${ }^{-2}, \chi^{2}$ are $\times 10^{-7}$.

\begin{tabular}{|c|c|c|c|c|c|c|c|c|c|c|c|c|}
\hline \multirow[b]{2}{*}{ Setting } & \multicolumn{3}{|c|}{ Global } & \multicolumn{3}{|c|}{ Amazon (AMA) } & \multicolumn{3}{|c|}{ Southeast US (SEUS) } & \multicolumn{3}{|c|}{ Pacific Ocean (PAC) } \\
\hline & Mean & $\pm 1 \sigma$ & $\chi^{2}$ & Mean & $\pm 1 \sigma$ & $\chi^{2}$ & Mean & $\pm 1 \sigma$ & $\chi^{2}$ & Mean & $\pm 1 \sigma$ & $\chi^{2}$ \\
\hline Reference retrieval & -0.30 & 0.57 & 8.96 & 1.01 & 0.33 & 7.64 & 1.14 & 0.32 & 6.40 & -0.35 & 0.15 & 6.28 \\
\hline \multicolumn{13}{|l|}{ Spectral range } \\
\hline \multicolumn{13}{|l|}{$\mathrm{BrO}$ window } \\
\hline 1a. $332-359 \mathrm{~nm}$ & -0.24 & 0.57 & 8.95 & 1.01 & 0.34 & 7.65 & 1.21 & 0.32 & 6.39 & -0.29 & 0.16 & 6.27 \\
\hline 1b. $332-359 \mathrm{~nm}(+\mathrm{OClO})$ & -0.15 & 0.56 & 8.92 & 1.09 & 0.35 & 7.63 & 1.27 & 0.32 & 6.37 & -0.21 & 0.16 & 6.25 \\
\hline 1c. Pre-fit $\mathrm{BrO}$ and $\mathrm{O}_{3}$ & -0.28 & 0.58 & 9.09 & 1.03 & 0.33 & 7.70 & 1.19 & 0.32 & 6.39 & -0.34 & 0.15 & 6.31 \\
\hline \multicolumn{13}{|l|}{$\mathrm{CH}_{2} \mathrm{O}$ window } \\
\hline 2a. $325.5-350 \mathrm{~nm}$ & 0.27 & 0.61 & 10.91 & 1.37 & 0.29 & 8.96 & 1.64 & 0.31 & 7.26 & 0.07 & 0.14 & 7.39 \\
\hline 2b. $332-350 \mathrm{~nm}$ & -0.38 & 0.59 & 10.19 & 0.99 & 0.37 & 8.78 & 1.09 & 0.33 & 7.18 & -0.41 & 0.16 & 7.17 \\
\hline 2c. 337.5-359 nm (GOME-1) & -1.48 & 0.75 & 13.34 & 0.02 & 0.47 & 11.95 & 0.03 & 0.38 & 9.73 & -1.50 & 0.17 & 9.57 \\
\hline 2d. 327.5-356.6 nm (OMI) & -0.35 & 0.63 & 11.39 & 0.75 & 0.31 & 9.45 & 0.98 & 0.32 & 7.64 & -0.56 & 0.13 & 7.59 \\
\hline \multicolumn{13}{|l|}{ Absorber effects } \\
\hline 3a. Ring (Chance and Spurr, 1997) & -0.03 & 0.60 & 46.57 & 1.30 & 0.34 & 39.58 & 1.45 & 0.33 & 37.17 & -0.05 & 0.16 & 41.80 \\
\hline 3b. $\mathrm{O}_{4}$ & -0.16 & 0.54 & 8.88 & 1.12 & 0.36 & 7.55 & 1.20 & 0.32 & 6.37 & -0.22 & 0.16 & 6.22 \\
\hline 3c. $\mathrm{O}_{4}$ (GOME-1 window) & -1.38 & 0.77 & 13.12 & 0.10 & 0.49 & 11.82 & 0.08 & 0.38 & 9.67 & -1.41 & 0.18 & 9.46 \\
\hline $3 \mathrm{~d} . \mathrm{O}_{4}$ (3rd order poly) & 0.64 & 0.55 & 9.11 & 1.81 & 0.33 & 7.64 & 2.01 & 0.33 & 6.37 & 0.51 & 0.14 & 6.22 \\
\hline 3e. OClO & -0.40 & 0.59 & 8.81 & 0.92 & 0.35 & 7.58 & 1.06 & 0.34 & 6.37 & -0.51 & 0.16 & 6.21 \\
\hline 3f. No wav. calibration & -1.11 & 0.64 & 9.51 & 0.33 & 0.33 & 7.99 & 0.38 & 0.32 & 6.87 & -1.03 & 0.15 & 6.59 \\
\hline $3 \mathrm{~g} . \mathrm{I}_{0}$ correct all abs. & -0.30 & 0.55 & 8.89 & 1.02 & 0.32 & 7.57 & 1.10 & 0.32 & 6.34 & -0.32 & 0.15 & 6.22 \\
\hline \multicolumn{13}{|l|}{ Polynomial degree } \\
\hline 4a. 4 th order polynomial & 0.01 & 0.61 & 9.19 & 1.25 & 0.31 & 7.76 & 1.45 & 0.33 & 6.52 & -0.14 & 0.14 & 6.39 \\
\hline 4b. 3rd order polynomial & -0.35 & 0.72 & 9.69 & 0.89 & 0.30 & 8.09 & 1.23 & 0.34 & 6.63 & -0.45 & 0.15 & 6.64 \\
\hline \multicolumn{13}{|l|}{ Instrument corrections } \\
\hline 5a. No scan bias correction & 0.10 & 0.57 & 8.85 & 1.34 & 0.32 & 7.56 & 1.48 & 0.32 & 6.33 & 0.00 & 0.14 & 6.19 \\
\hline 5b. No undersampling & -0.17 & 0.56 & 9.17 & 1.05 & 0.33 & 7.71 & 1.29 & 0.33 & 6.53 & -0.31 & 0.16 & 6.36 \\
\hline 5c. No linear offset & -1.34 & 0.62 & 10.35 & 0.22 & 0.34 & 8.37 & 0.22 & 0.33 & 7.27 & -1.59 & 0.14 & 7.77 \\
\hline $5 \mathrm{~d} .0$ order offset correction & -1.13 & 0.62 & 9.78 & 0.38 & 0.34 & 8.15 & 0.42 & 0.33 & 7.00 & -1.27 & 0.14 & 7.08 \\
\hline 5e. 2 nd order offset correction & -0.24 & 0.56 & 8.84 & 1.07 & 0.33 & 7.56 & 1.19 & 0.32 & 6.36 & -0.30 & 0.15 & 6.25 \\
\hline 5f. $1 / \mathrm{I}_{0}$ offset correction & -1.15 & 0.61 & 9.94 & 0.35 & 0.34 & 8.13 & 0.38 & 0.33 & 6.99 & -1.33 & 0.14 & 7.11 \\
\hline
\end{tabular}

Taking the pre-fitting concept further, Chance et al. (2000) have previously applied a three-step fitting procedure to GOME-1 data, fixing both $\mathrm{BrO}$ and $\mathrm{O}_{3}$ in the $\mathrm{CH}_{2} \mathrm{O}$ window to pre-fitted values from preferential fitting windows. Test $1 \mathrm{c}$ applies this method with an $\mathrm{O}_{3}$ pre-fit in the 325$335 \mathrm{~nm}$ window (using the basic $\mathrm{O}_{3}$ retrieval settings from Loyola et al., 2011a), along with the default BrO pre-fit detailed above. This two-way pre-fit shows a slight but noticeable increase in $\mathrm{CH}_{2} \mathrm{O}$ slant columns and fit $\chi^{2}$, suggesting for GOME-2 that the application of a further pre-fit is not worth the extra computation required. It should be noted, however, that the extra fit windows applied for the pre-fits are in a slightly different wavelength range to that of the $\mathrm{CH}_{2} \mathrm{O}$ retrieval, particularly so for the extra $\mathrm{O}_{3}$ pre-fit. Whilst slant columns for these extra absorbers are optimised with the intention of yielding a more accurate retrieval than found with the $\mathrm{CH}_{2} \mathrm{O}$ fit window alone, the subsequent value passed into the $\mathrm{CH}_{2} \mathrm{O}$ section of fitting is likely to be a different slant column than would have been found with the $\mathrm{CH}_{2} \mathrm{O}$ specific window, thereby modifying the $\mathrm{CH}_{2} \mathrm{O}$ slant column as a function of this difference. One method which may alleviate some of these issues would be the application of a weighting function DOAS (WF-DOAS) type algorithm, accounting for the wavelength dependency of the various absorbers included in the fit (Buchwitz et al., 2000). Having been successfully applied to UV retrievals of $\mathrm{O}_{3}$ from GOME spectra (Coldewey-Egbers et al., 2005), application of WF-DOAS to minor absorbers in the UV has also shown promise, successful retrievals of $\mathrm{SO}_{2}$ from SCIAMACHY data proving its efficacy (Lee et al., 2008).

Margins between differing $\mathrm{BrO}$ pre-fit windows are small, in terms of both retrieved $\mathrm{CH}_{2} \mathrm{O}$ slant columns and fit residuals. Given the slightly higher $\mathrm{CH}_{2} \mathrm{O}$ slant columns and very small increases in fit quality found with test $1 \mathrm{a}$, adjusting the pre-fit window to the new range may well appear justified, in line with Theys et al. (2011) findings of an improved $\mathrm{BrO}$ fit in this region. In relation to the pre-fit wavelength dependence interplay, by discarding spectra taken at an SZA of $>60^{\circ}$, the issues of spurious $\mathrm{BrO}$ and/or $\mathrm{O}_{3}$ values modifying the $\mathrm{CH}_{2} \mathrm{O}$ fit are mitigated for, given the proportionally reduced columns of these absorbers typically expected in the latitudes covered by an SZA $<60^{\circ}$. 


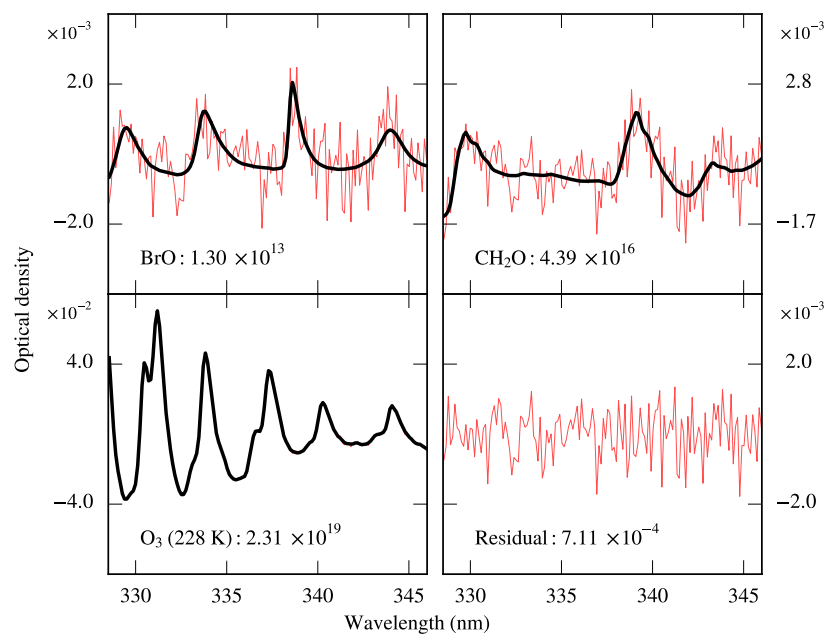

Fig. 2. Example $\mathrm{CH}_{2} \mathrm{O}$ fit using the reference retrieval settings for an enhanced $\mathrm{CH}_{2} \mathrm{O}$ plume over the southeast USA on $9 \mathrm{Au}-$ gust 2007 (scan 3107, orbit 4176, SZA 28.8 ${ }^{\circ}$ ). $\mathrm{NO}_{2}$, Ring, undersampling, polynomial fit, and linear offset are omitted from the plot but included in the fit; slant column units are in molecules $\mathrm{cm}^{-2}$.

\subsection{2 $\mathrm{CH}_{2} \mathrm{O}$}

Shown in Fig. 3, the dependence of retrieved slant column and its error on the chosen fit window is demonstrated by repeatedly performing a DOAS fit on a single pixel (covering a region of strong $\mathrm{CH}_{2} \mathrm{O}$ emissions), incrementally adjusting the upper and lower fit window limits with a $0.5 \mathrm{~nm}$ step. The lowest band of fit residuals (the remaining spectrum following the fitting of the modelled spectrum to our measured Earthshine spectrum) is found with a lower fit range between 328 and $329 \mathrm{~nm}$, coinciding with the second major $\mathrm{CH}_{2} \mathrm{O}$ absorption peak, whilst slant column error serves to provide an estimate of the upper window cut-off, displaying a band of error minima in the $345-349 \mathrm{~nm}$ region.

In test $2 \mathrm{a}$ we retrieve in the $325.5-350 \mathrm{~nm}$ fit range used by Marbach et al. (2010), taking in the strongest $\mathrm{CH}_{2} \mathrm{O}$ absorption peak available $(326 \mathrm{~nm})$ in the UV as well as an extra $\mathrm{BrO}$ peak towards the visible. Whilst fitting in this region is seen to substantially increase $\mathrm{CH}_{2} \mathrm{O}$ slant columns $\left(+0.57 \times 10^{16}\right.$ molecules $\mathrm{cm}^{-2}$ globally $)$, fitting quality similarly increases $1.95 \times 10^{-7}$, pointing towards significant amounts of spectral interference from the wider band of strong $\mathrm{O}_{3}$ absorption in the lower UV. A newly proposed fit region, $332-350 \mathrm{~nm}$ is tested for test $2 \mathrm{~b}$, with the intention of avoiding the worst $\mathrm{O}_{3}$ absorption in the lower fit range. This sees a global reduction on $\mathrm{CH}_{2} \mathrm{O}$ slant columns of $-0.08 \times 10^{16}$ molecules $\mathrm{cm}^{-2}$, along with noticeable increases in $\chi^{2}\left(1.23 \times 10^{-7}\right.$ globally); suggesting exclusion of the $\mathrm{CH}_{2} \mathrm{O}$ absorption peak around $330 \mathrm{~nm}$ imparts a significant negative effect on retrievals, providing an insufficient number of peaks with which to accurately discriminate $\mathrm{CH}_{2} \mathrm{O}$ from its conflicting absorbers.

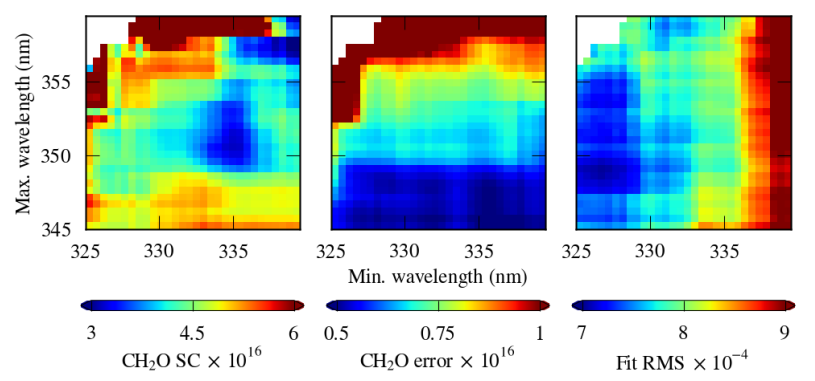

Fig. 3. This surface plot (scan number 3107, orbit 4176) takes the reference retrieval and adjusts the upper and lower limits of the $\mathrm{CH}_{2} \mathrm{O}$ fit window in $0.5 \mathrm{~nm}$ increments, revealing the large variations in slant column and concurrent errors to be found within the $\mathrm{CH}_{2} \mathrm{O}$ fitting window. Note areas of low slant column error and fit RMS coincide well with the baseline retrieval window of $328.5-346 \mathrm{~nm}$ on the $\mathrm{x}$ and $\mathrm{y}$ axis, respectively. Differences between $\mathrm{CH}_{2} \mathrm{O}$ error and fit residuals are suggested to be attributed to variation in the error covariance matrix as the fit boundary is adjusted (M. Van Roozendael, personal communication, 2012).

Testing similar space-borne UV spectrometer retrieval windows on GOME-2 data shows the trend in slant column reduction continues as we move to the lower end of the window further from the UV. In $2 \mathrm{c}$ we test the 337.5$359 \mathrm{~nm}$ fit window refined for use with the original GOME instrument (Chance et al., 2000; Wittrock et al., 2000). With the fit window lower limit at $337.5 \mathrm{~nm}$, correlations between $\mathrm{CH}_{2} \mathrm{O}$ and $\mathrm{O}_{3}$ spectra should be minimised in the DOAS fit - moving into a region of greatly reduced $\mathrm{O}_{3}$ strength compared to the $\mathrm{CH}_{2} \mathrm{O}$ absorption spectra. However, reduction in the $\mathrm{O}_{3}$ correlation comes at the cost of greatly reduced fit quality $\left(-4.38 \times 10^{-7}\right.$ globally) and major reductions in $\mathrm{CH}_{2} \mathrm{O}$ slant columns $\left(-1.18 \times 10^{16}\right.$ molecules $\left.\mathrm{cm}^{-2}\right)$ due to increased interference from $\mathrm{BrO}$ and $\mathrm{O}_{4}$. Comparable in wavelength range to GOME-2, the OMI sensor also provides spectra for $\mathrm{CH}_{2} \mathrm{O}$ column retrievals using a GOME type spectral fitting algorithm (Chance, 2002; Kurosu et al., 2004). Test $2 \mathrm{~d}$ applies the suggested OMI retrieval window $(327.5-356.6 \mathrm{~nm})$ on the GOME-2 data (in conjunction with the standard $\mathrm{BrO}$ pre-fit), leading to a global decrease in fit $\chi^{2}$ of $-2.43 \times 10^{-7}$ compared to the reference retrieval, whilst we observe continental $\mathrm{CH}_{2} \mathrm{O}$ slant column decreases of -0.26 and $-0.16 \times 10^{16}$ molecules $\mathrm{cm}^{-2}$ for the AMA and SEUS regions.

From tests $2 \mathrm{a}-\mathrm{d}$, it is apparent that the differences between various spectrometers limit applications of fit windows as specific to each instrument. Sensitivity to unknown instrumental or atmospheric absorption features towards $350 \mathrm{~nm}$ precludes use of the original GOME and $\mathrm{OMI} \mathrm{CH}_{2} \mathrm{O}$ fit windows due to their use of a higher wavelength cut-off. Nevertheless, a good retrieval is possible with the lower fitting range as applied in the reference fit, with Fig. 3 demonstrating a minimisation of fit RMS is achieved, coupled to strongly enhanced $\mathrm{CH}_{2} \mathrm{O}$ slant columns expected of the SEUS study site. 


\subsection{Absorber effects}

\subsubsection{Ring effect}

Modelling of the Ring effect is accounted for with the inclusion of Ring spectra as pseudo-absorbers in the retrieval. In the reference retrieval, the method of Vountas et al. (1998) is applied to Ring cross sections generated with the SCIATRAN radiative transfer model (Rozanov et al., 2005), accounting for both Fraunhofer and molecular Ring effects. The widely used alternative method of Chance and Spurr (1997) applies only one pseudo-absorber in the retrieval, assuming the molecular contribution to Ring effect can safely be ignored. Applying this alternative Ring model (in DOAS mode) in test 3a shows large increases in $\mathrm{CH}_{2} \mathrm{O}$ slant columns $\left(+0.27 \times 10^{16}\right.$ molecules $\left.\mathrm{cm}^{-2}\right)$, coincident with dramatic reductions in fit quality for all regions demonstrated by a global $\chi^{2}$ of $46.57 \times 10^{-7}$. Despite these relatively poor results compared to the 2 Ring cross section method (Vountas et al., 1998), the Chance and Spurr (1997) method is recommended to be applied in the modified DOAS algorithm, fitting intensity, rather than a linear least-squares fitting of the differential optical depth, as applied here. In either instance, further increases in fit quality can be expected with an improved Ring term, taking into account scene-specific parameters on albedo, aerosol loading, and clouds. However, given the range of variables involved in this process, this is considered beyond the scope of this study.

\subsection{2 $\mathrm{O}_{4}$ inclusion}

When using a narrow window from $328.5-346 \mathrm{~nm}$, the reference $\mathrm{CH}_{2} \mathrm{O}$ window upper limit correlates well with an $\mathrm{O}_{4}$ absorption minimum, which when combined with application of a 5th order polynomial, should negate significant $\mathrm{O}_{4}$ interference in this region (De Smedt et al., 2008). Testing the inclusion of $\mathrm{O}_{4}$ shows a minor decrease in global $\chi^{2}$, corresponding to an increase of $\mathrm{CH}_{2} \mathrm{O}$ slant columns. The possibility of an $\mathrm{O}_{4}$ incursion in the upper fitting region, where $\mathrm{O}_{4}$ absorption is strongest, has been explored for desert regions by De Smedt et al. (2008) and further tested here.

Tests $3 \mathrm{~b}, \mathrm{c}$ and $\mathrm{d}$ include the Greenblatt et al. (1990) $\mathrm{O}_{4}$ cross section as an extra absorber. Its inclusion in the reference fit alone (test $3 b$ ) increases $\mathrm{CH}_{2} \mathrm{O}$ slant columns for global and PAC regions by 0.14 and $0.08 \times 10^{16}$ molecules $\mathrm{cm}^{-2}$, respectively, with less noticeable effects for the enhanced $\mathrm{CH}_{2} \mathrm{O}$ regions. In all $\mathrm{O}_{4}$ tests, fit $\chi^{2}$ is modulated within $\sim 1 \%$ of the reference retrieval. In $3 \mathrm{c}$ we adjust the fit window to that of the GOME-1 fitting region, a wavelength range in which $\mathrm{O}_{4}$ exhibits significant absorption features. Compared to test $2 \mathrm{c}$ (same fit region, no $\mathrm{O}_{4}$ fitted), retrieved $\mathrm{CH}_{2} \mathrm{O}$ slant columns increase by $\sim 0.1 \times 10^{16}$ molecules $\mathrm{cm}^{-2}$, a value not dissimilar to the $0.14 \times 10^{16}$ molecules $\mathrm{cm}^{-2}$ increase for test $3 \mathrm{~b}$ against the reference retrieval.

In test $3 d$ we test the effectiveness of the reference retrieval's 5th order polynomial by replacing it with a 3rd order polynomial and fitting $\mathrm{O}_{4}$, as previously applied to GOME1 retrievals (albeit in a higher wavelength range) (Wittrock et al., 2000). This offers a significantly different result to the reference retrieval, not demonstrated by alternate $\mathrm{O}_{4}$ permutations in the tests above. $\mathrm{CH}_{2} \mathrm{O}$ slant columns are retrieved $0.94 \times 10^{16}$ molecules $\mathrm{cm}^{-2}$ higher globally, the majority of which are accounted for by higher retrievals over oceans, with a slightly reduced fit quality ( $\sim 1.74 \%$ globally). These results suggest the 5 th order polynomial, in conjunction with the shift in fit region to lower wavelengths, is accounting for additional unquantified instrumental and/or atmospheric artefacts beyond the broadband atmospheric absorption processes typically modelled by a $3 \mathrm{rd}$ order polynomial in the fitting region.

\subsubsection{OClO inclusion}

Including the Bogumil et al. (2003) OClO cross section (convolved to the GOME-2 slit function) in both fit windows is seen to affect $\mathrm{CH}_{2} \mathrm{O}$ slant columns less substantially than with $\mathrm{O}_{4}$, where slight decreases in fit residuals are displayed (alluded to from its inclusion in $\mathrm{BrO}$ pre-fit window tests), concurrent with a global reduction in $\mathrm{CH}_{2} \mathrm{O}$ slant columns of approximately a third. However, OClO's presence is inhomogenous over the globe, being largely confined to stratospheric polar regions, and active during polar springtime (Oetjen et al., 2011). By discarding scans with SZA $>60^{\circ}, \mathrm{OClO}$ should not present a problem for $\mathrm{CH}_{2} \mathrm{O}$, elevated concentrations of which are largely confined to mid-latitudinal tropical regions. However, due to similarities between $\mathrm{CH}_{2} \mathrm{O}$ and $\mathrm{OClO}$ absorption cross sections, signal contamination cannot be completely ruled out. False OClO detection in tropical tropospheric regions will lead to a reduction in $\mathrm{CH}_{2} \mathrm{O}$ column's, whilst an $\mathrm{OClO}$ contaminated signal in poleward regions may well yield artificially enhanced $\mathrm{CH}_{2} \mathrm{O}$ values. Test $3 \mathrm{~d}$ includes $\mathrm{OClO}$ in the DOAS fit, yielding lower $\mathrm{CH}_{2} \mathrm{O}$ values over the $\mathrm{Pa}$ cific Ocean $\left(-0.16 \times 10^{16}\right.$ molecules $\left.\mathrm{cm}^{-2}\right)$, together with slightly decreased slant columns for AMA and SEUS regions $\left(-0.09\right.$ and $0.08 \times 10^{16}$ molecules $\left.\mathrm{cm}^{-2}\right)$ and a moderate global reduction in fit RMS $\left(-0.04 \times 10^{-4}\right)$.

\subsubsection{Wavelength calibration}

Although an extensive pre-flight characterisation campaign for the GOME-2 instrument (Siddans et al., 2006) has allowed for a superior operational wavelength calibration compared with its predecessor, additional wavelength calibration on reference spectra prior to application of DOAS fitting is deemed essential. To test the usefulness of this extra calibration, the wavelength calibration step is omitted from the 
reference retrieval in test $3 \mathrm{f}$. This results in a global reduction of $\mathrm{CH}_{2} \mathrm{O}$ slant columns by $0.81 \times 10^{16}$ molecules $\mathrm{cm}^{-2}$, coupled to an amplification in global latitudinal bias evident in the geographical distribution (see Fig. 4). Fit quality is reduced, with $\chi^{2}$ deteriorating at a global scale (by $0.55 \times 10^{-7}$ ). This shows the improved wavelength calibration allows for an enhanced alignment of absorption features in spectra and trace gas cross sections, crucial in improving the accuracy of $\mathrm{O}_{3}$ and $\mathrm{BrO}$ fits, particularly at large SZAs.

\subsection{5 $I_{0}$ correction}

Following the methodology of Aliwell et al. (2002), $\mathrm{O}_{3}$ cross sections included in the reference retrieval are corrected for the $\mathrm{I}_{0}$ effect. The baseline retrieval followed here incorporates a slant column of $0.8 \times 10^{19}$ molecules $\mathrm{cm}^{-2}$ in $\mathrm{O}_{3}$ cross sections prior to fitting (our reference retrieval shows $\mathrm{O}_{3}$ retrieved in the slightly wider $\mathrm{BrO}$ pre-fitting window to be close enough to values retrieved in the $\mathrm{CH}_{2} \mathrm{O}$ window to warrant using the same correction value). The slant column incorporated in cross sections remains a source of error in the retrieval, typically set to the maximum retrieved slant column value of the corrected absorber. This value can be expected to exhibit wide seasonal and geographic variation. For orbit 4176 , the scaling factor is adjusted in $0.1 \times 10^{19}$ molecules $\mathrm{cm}^{-2}$ steps between 0.1 and $2.3 \times 10^{19}$ molecules $\mathrm{cm}^{-2}$ to evaluate the range of retrieval effects imparted by the correction.

Figure 5 shows the results of this test, with a levelling off of $\mathrm{CH}_{2} \mathrm{O}$ slant columns and errors, $\mathrm{O}_{3}$ and fit residuals when the slant column is increased above $0.5 \times 10^{19}$ molecules $\mathrm{cm}^{-2}$. Assuming the retrievals from orbit 4176 are reasonably illustrative of a typical GOME2 orbit, this indicates incorporation of an $\mathrm{O}_{3}$ column at $0.5 \times 10^{19}$ molecules $\mathrm{cm}^{-2}$ represents an appropriate correction factor. Extending the application of $\mathrm{I}_{0}$ correction from just $\mathrm{O}_{3}$ to all trace gas absorbers in test $3 \mathrm{~g}\left(\mathrm{BrO}\right.$ at $4.5 \times 10^{14}$, $\mathrm{CH}_{2} \mathrm{O}$ at $12 \times 10^{16}$, and $\mathrm{NO}_{2}$ at $5 \times 10^{17}$ ) yields negligible global increases in $\mathrm{CH}_{2} \mathrm{O}$ slant columns, with accompanying increases in fit quality of $0.07 \times 10^{-7}$. However, these changes are not uniform across the globe, with slant columns increases for the AMA and PAC regions, and decreases evident for SEUS. These further increases in fit quality suggest extending the $\mathrm{I}_{0}$ correction methodology to all fitted trace gas absorbers is warranted.

\subsubsection{Cross section temperature}

Change in absorption spectra line shape and strength are frequently encountered in parallel with temperature variations. Of relevance here, $\mathrm{O}_{3}$ absorption cross sections show a strong relationship with both temperature and pressure (Liu et al., 2007), and are therefore included in the retrieval at two temperatures, orthogonalised to one another. Tropospheric $\mathrm{CH}_{2} \mathrm{O}$ retrievals typically fit $\mathrm{O}_{3}$ at temperatures suitable to

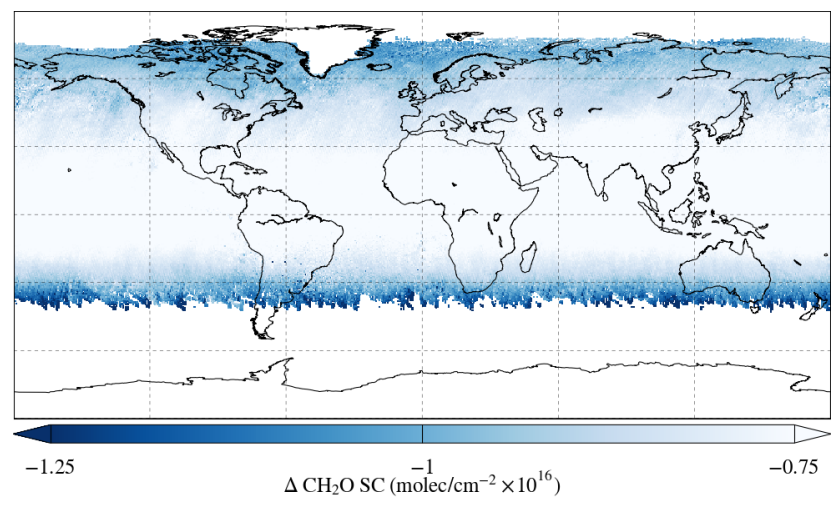

Fig. 4. Difference plot on monthly mean for test 3f, excluding wavelength calibration. Dark fringes at the latitudinal extremes of the retrievals indicate $\mathrm{CH}_{2} \mathrm{O}$ slant columns are strongly depressed in these regions, primarily as a function of increased $\mathrm{O}_{3}$ interference.

the stratospheric $\mathrm{O}_{3}$ component, at around $218-228 \mathrm{~K}$ and 241-248 K.

To test the dependence of $\mathrm{CH}_{2} \mathrm{O}$ slant column on $\mathrm{O}_{3}$ retrieval temperature, we apply temperature coefficients given with the Liu et al. (2007) interpretation of the Malicet et al. (1995) $\mathrm{O}_{3}$ cross sections, thus allowing accurate derivation of $\mathrm{O}_{3}$ absorption cross sections at any number of temperatures. As shown in Fig. 6, the variability is assessed for a single scan over the SEUS study site, on the $9 \mathrm{Au}-$ gust 2007 (scan no. 3107, orbit 4176), when a high $\mathrm{CH}_{2} \mathrm{O}$ slant column magnitude is expected. The $\mathrm{O}_{3}$ temperature range is adjusted through $200-230 \mathrm{~K}$ and $230-260 \mathrm{~K}$ in $0.5 \mathrm{~K}$ intervals, altering retrieved $\mathrm{CH}_{2} \mathrm{O}$ slant columns between $4.0-4.8 \times 10^{16}$ molecules $\mathrm{cm}^{-2}$, and $\mathrm{O}_{3}$ slant column from $2.20-2.30 \times 10^{19}$ molecules $\mathrm{cm}^{-2}$. Temperature effects on fit residuals are limited to a small range of $\mathrm{O}_{3}$ temperature combinations for $<215 \mathrm{~K}$ (lower) and $>245 \mathrm{~K}$ (upper), beyond which they flatten out around $7.1 \times 10^{-4}$. This large range of minimised fit residuals allows optimisation of the $\mathrm{CH}_{2} \mathrm{O}$ fit according to the maximum slant columns. For $\mathrm{CH}_{2} \mathrm{O}$ and $\mathrm{O}_{3}$, both suggest temperatures currently in use are entirely suitable (i.e. 228 and $243 \mathrm{~K}$, respectively).

The $\mathrm{CH}_{2} \mathrm{O}$ cross section varies throughout the UV absorption region (Brauers et al., 2007). To arrive at an appropriate error estimate for $\mathrm{CH}_{2} \mathrm{O}$ temperature dependency, $\mathrm{CH}_{2} \mathrm{O}$ cross sections were generated at $5 \mathrm{~K}$ temperature intervals between 273 and $308 \mathrm{~K}$, and applied in place of the regular $\mathrm{CH}_{2} \mathrm{O}$ cross section $(298 \mathrm{~K})$. The mean temperature dependency over orbit 4176 is found to be weak, at only $\sim 0.03 \times 10^{16}$ molecules $\mathrm{cm}^{-2}$ over the $35 \mathrm{~K}$ temperature range tested, translating to an average decrease in $\mathrm{CH}_{2} \mathrm{O}$ slant column of $0.11 \% \mathrm{~K}^{-1}$.

Selecting two $5^{\circ} \times 5^{\circ}$ regions of high (southeastern USA) and low (Gulf of Mexico) $\mathrm{CH}_{2} \mathrm{O}$ concentrations from the orbit provides a more detailed estimate of the temperature dependency. $\mathrm{O}_{3}$ slant columns remain unaffected by the 


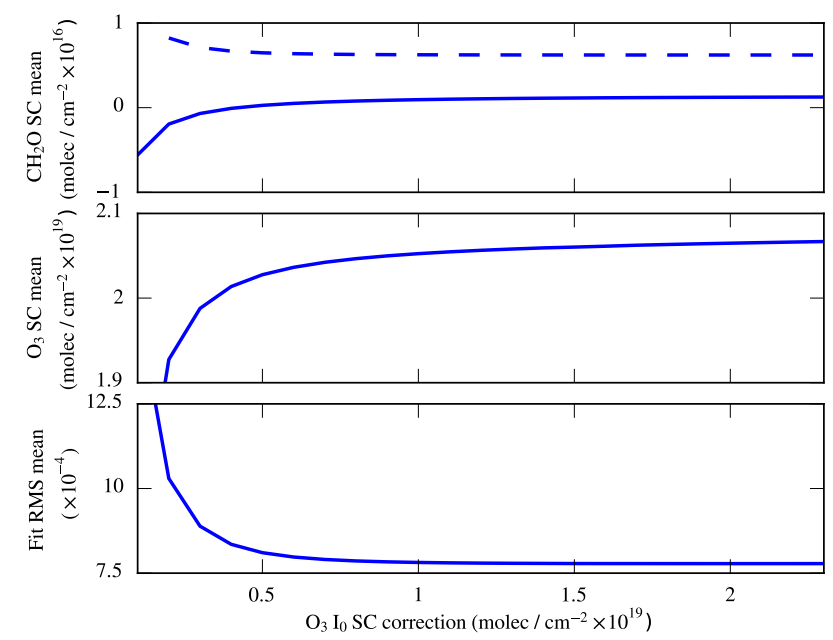

Fig. 5. $I_{0}$ correction range test showing mean values for orbit 4176, with the $\mathrm{O}_{3}$ column slant column adjusted at $0.1 \times 10^{19}$ molecules $\mathrm{cm}^{-2}$ intervals along the $\mathrm{x}$-axis (the reference retrieval applies an add back value of $0.8 \times 10^{19}$ molecules $\mathrm{cm}^{-2}$ ). Dashed line indicates mean $\mathrm{CH}_{2} \mathrm{O}$ slant column error.

adjustment of $\mathrm{CH}_{2} \mathrm{O}$ absorption cross section temperature. Corresponding to the increased cross section temperature, $\mathrm{CH}_{2} \mathrm{O}$ slant column mean increases in a linear fashion $+0.16 \times 10^{16}$ molecules $\mathrm{cm}^{-2}$ across the temperature range for the enhanced SEUS $\mathrm{CH}_{2} \mathrm{O}$ plume, with a much smaller increase for the low $\mathrm{CH}_{2} \mathrm{O}$ slant column case, increasing by just $0.01 \times 10^{16}$ molecules $\mathrm{cm}^{-2}$.

$\mathrm{CH}_{2} \mathrm{O}$ cross section temperature would ideally be selected appropriate to environmental conditions at the time of spectra observation. However, given the small likelihood of information on tropospheric temperatures being available to the user, application of a single effective temperature for tropospheric $\mathrm{CH}_{2} \mathrm{O}$ absorption for the entire orbit may represent the most practical solution. In this instance, for tropospheric mid-latitude $\mathrm{CH}_{2} \mathrm{O}$ retrievals, a temperature of $298 \mathrm{~K}$ would seem applicable.

\subsection{Polynomial degree}

Fitting the GOME-2 measured Earthshine spectrum with a polynomial removes the broadband spectral component of atmospheric Rayleigh and Mie scattering prior to fitting trace gas absorbers. Work with the original GOME instrument found application of a 3rd order polynomial sufficient to remove the atmospheric scattering component (Wittrock et al., 2000). However, with the shift of the fit range further into the $\mathrm{UV}$, allowing stronger $\mathrm{O}_{3}$ absorption to increase retrieval interference, a 5th order polynomial is applied in the reference settings, based on the work of De Smedt et al. (2012). Test 4a applies a 4th order polynomial, resulting in an approximate doubling of slant columns over oceans, with gains in $\mathrm{CH}_{2} \mathrm{O}$ slant column of $0.24 \times 10^{16}$ molecules $\mathrm{cm}^{-2}$ for AMA, and

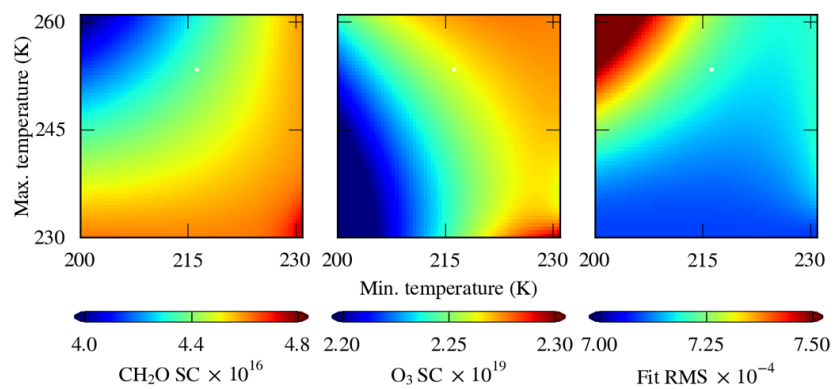

Fig. 6. Scan number 3107 (orbit 4176) repeatedly retrieved with the reference settings, adjusting the low and high temperatures of the orthogonalised $\mathrm{O}_{3}$ absorption spectra in increments of $0.5 \mathrm{~K}$. A linear gradient is seen for slant columns (molecules $\mathrm{cm}^{-2}$ ) and fit residuals. Whilst the range of fit residual variation is not large, the retrieved $\mathrm{CH}_{2} \mathrm{O}$ slant column displays a non-negligible range of values.

$0.31 \times 10^{16}$ molecules $\mathrm{cm}^{-2}$ for SEUS. Application of a $3 \mathrm{rd}$ order polynomial in test $4 \mathrm{~b}$ increases the strength of the latitudinal dependency globally (reducing values at high latitudes, with increased slant columns at mid-latitudes), yielding a global $\mathrm{CH}_{2} \mathrm{O}$ slant column increase of around $15 \%$. Fit quality for both tests is seen to greatly reduce $\left(+0.23 \times 10^{-7}\right.$ for the 4 th order, and $+0.73 \times 10^{-7}$ for the 3 rd globally) from the reference retrieval as we move away from the 5th order polynomial, showing lower order polynomials provide a comparatively poorer correction for atmospheric scattering processes in the fitting range applied here.

\subsection{Instrument corrections}

In a similar fashion to modelling atmospheric absorbers as accurately as possible presented in Sect. 3.2, mitigation must be made for known instrumental issues. In many cases this can be conducted by the addition of pseudo-absorbers representing spectral artefacts.

\subsubsection{Scan bias}

GOME-2 exhibits a scan angle and SZA dependent bias, occurring as a function of instrument degradation since launch (Cai et al., 2012). This is known to affect all GOME-2 retrievals, particularly those making use of short UV wavelengths (Balis et al., 2008; Antón et al., 2009; Loyola et al., 2011b). To counter this scan bias, Eta and Zeta polarisation spectra (measured pre-launch) are included in the reference retrieval $\mathrm{BrO}$ pre-fit window as pseudo-absorbers. Visual inspection of individual orbits reveal the values retrieved for the Eta and Zeta parameters display distinctive east and west components. Confirmation of the corrective effect is made in test $5 \mathrm{a}$ by testing the retrieval without the spectra and examining individual swaths, allowing a strong cross track dependency to become apparent, highlighted by eastern slant columns retrieving between 


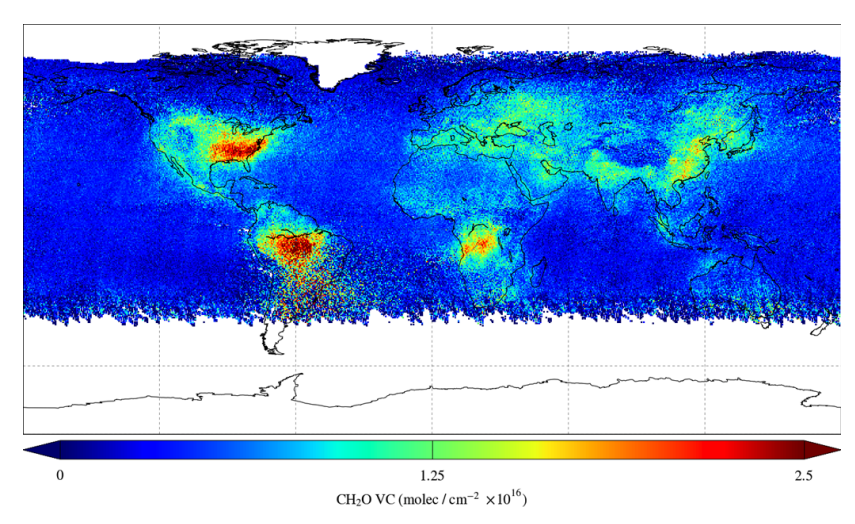

Fig. 7. Monthly mean $\mathrm{CH}_{2} \mathrm{O}$ vertical columns for August 2007 retrieved using the default algorithm settings (Table 1), after the application of the reference sector correction (see Sect. 4.2). Data are averaged onto a $0.5^{\circ} \times 0.5^{\circ}$ grid excluding observations with cloud fraction $>0.4$ and SZA $>60^{\circ}$.

$1-2 \times 10^{16}$ molecules $\mathrm{cm}^{-2}$ higher than their western counterparts over clear ocean, manifesting in a globally increased $\mathrm{CH}_{2} \mathrm{O}$ slant column mean $\left(0.4 \times 10^{16}\right.$ molecules $\left.\mathrm{cm}^{-2}\right)$. However, exclusion of these correction factors also serves to increase fit quality, with $\chi^{2}$ values decreasing for all sites. The inclusion of the scan bias correction's overall negative effect on fit quality points to the requirement for implementation of superior retrieval-based bias correction techniques such as that derived by Loyola et al. (2011b), or empirical corrections of L1B data.

\subsubsection{Spectral undersampling}

GOME-2 samples between 2.46 and 2.25 measurements per FWHM $(0.27 \mathrm{~nm})$ at the lower and upper wavelength limits of the reference fitting interval. Small wavelength shifts of the spectrometer in orbit, on the order of $0.007 \mathrm{~nm}$, introduce potential for undersampling of spectra, especially with a moderately decreasing FWHM towards the upper limit of the $\mathrm{CH}_{2} \mathrm{O}$ fit window (Cai et al., 2012). Undersampling spectra are calculated for GOME-2 following Chance et al. (2005), and included as a pseudo-absorber in the reference retrieval. Testing the efficacy of the undersampling correction by excluding the spectra from the fit in test $5 \mathrm{~b}$ leads to an increase of $+0.13 \times 10^{16}$ molecules $\mathrm{cm}^{-2}$ in $\mathrm{CH}_{2} \mathrm{O}$ slant columns globally, with similar increases for the study regions. Whilst the standard deviation on these columns decreases very slightly, confidence in the retrieval without an undersampling correction is undermined by significant reductions in fit quality for all sites. Loss of retrieval sensitivity from not correcting for undersampling, particularly for weak absorbers, suggests the inclusion of an undersampling correction should be strongly considered.

\subsubsection{Offset correction}

A small amount of signal measured by GOME-2 is thought to be additive from extraneous sources inherent to the imperfect nature of the instrument's design, construction and operation (e.g. stray light in the spectrometer housing, and degassing of adhesives and materials). These predominantly systematic artefacts can be accounted for by the addition of a linear offset term in the DOAS fit - typically taking the form of fitting a 1st order polynomial to the fit residual (as used in the reference fit here, derived following the modified offset equation detailed on page 69 of Fayt et al., 2011). This is tested in comparison with a 0 and 2 nd order offset polynomial (tests $5 \mathrm{~d}$ and $5 \mathrm{e}$ ), as well as application of a $1 / \mathrm{I}_{0}$ spectrum fitted as a pseudo-absorber (in place of the standard polynomial) (Marbach et al., 2010; Valks et al., 2011). The latter method, tested in 5f, has the potential to provide a more accurate representation of the offset term, being based on the instrument's physical parameters for each daily reference spectra.

Increasing the offset polynomial to a 2nd order correction increases fit quality very slightly ( $\sim 1 \%$ globally), with corresponding increases in $\mathrm{CH}_{2} \mathrm{O}$ slant column for all sites $\left(\sim 0.06 \times 10^{16}\right.$ molecules $\left.\mathrm{cm}^{-2}\right)$, suggesting the correction offers a superior modelling of instrumental offset. Application of a 0 order offset polynomial and a $1 / \mathrm{I}_{0}$ spectrum as the offset term both show similar significant reductions in slant columns, with fitting residuals increasing beyond that found with the reference correction term - rendering both alternatives unsuitable for further application to the $\mathrm{CH}_{2} \mathrm{O}$ retrieval.

\section{Sensitivity of $\mathrm{CH}_{2} \mathrm{O}$ vertical columns}

\subsection{Air mass factor calculation}

GOME-2 $\mathrm{CH}_{2} \mathrm{O}$ vertical columns are obtained by dividing the slant columns from the optimised retrieval settings, with air mass factor (AMF) values calculated offline using the approach of Palmer et al. (2001). As a full description of the AMF calculation is provided in Barkley et al. (2012), we only provide a short description. In brief, AMF look-up tables at $340 \mathrm{~nm}$ are constructed using the LIDORT radiative transfer model (Spurr et al., 2001), using monthly averaged $\mathrm{CH}_{2} \mathrm{O}$ profiles and aerosol optical depths, appropriate to GOME-2's overpass, from a global $4^{\circ}$ latitude $\times 5^{\circ}$ longitude GEOS-Chem chemistry transport model simulation. A description of the GEOS-Chem simulation can be found in Barkley et al. (2013). The monthly AMF look-up tables are parameterised as a function of solar zenith angle, viewing geometry, surface reflectance, and surface pressure. Partially cloudy pixels are taken into account with the independent pixel approximation method (Martin et al., 2002), with clouds treated as Lambertian reflectors with an albedo of 0.8 . Cloud fraction and cloud-top pressure are taken directly from the GOME-2 GDP4.0 FRESCO product (Wang et al., 2008). 
The surface reflectance in clear-sky conditions is taken from the TOMS climatology of Herman and Celarier (1997). The AMF is known to be a significant source of uncertainty in the $\mathrm{CH}_{2} \mathrm{O}$ vertical column retrieval (De Smedt et al., 2008; Barkley et al., 2012), and its impact on the GOME-2 retrieval will be examined in more detail in a future study.

\subsection{Reference sector correction}

To mitigate for unresolved spectral dependencies occurring at high latitudes between $\mathrm{CH}_{2} \mathrm{O}$ and strongly interfering $\mathrm{BrO}$ and $\mathrm{O}_{3}$ molecules, a reference sector correction (RSC) is performed following the standard procedure developed for stratospheric correction of $\mathrm{NO}_{2}$ retrievals (Martin et al., 2002; Richter and Burrows, 2002) and also routinely applied to $\mathrm{CH}_{2} \mathrm{O}$ data (e.g. Palmer et al., 2006; Barkley et al., 2008; De Smedt et al., 2008). Slant columns from the reference strip of clean Pacific air between $140-160^{\circ} \mathrm{W}$ longitude, representing a constant local time due to MetOp-A's sun-synchronous orbit, are latitudinally fitted with a 3rd order polynomial, and the latitude-dependent fitted slant column from this strip is subtracted globally from each day's measurements to serve as a daily correction. $\mathrm{CH}_{2} \mathrm{O}$ concentrations in this Pacific Ocean region are representative of global background levels generated by methane oxidation. Differences from this subtraction are attributed to unresolved spectral interferences and latitudinal dependency of the sub-optimal $\mathrm{O}_{3}$ retrieval. Vertical columns are then derived by dividing bias free slant columns with previously generated AMFs. Finally, latitudinal means of GEOS-Chem model data (also fitted with a 3rd order polynomial over the same Pacific Ocean reference strip) are added back to generate the final corrected $\mathrm{CH}_{2} \mathrm{O}$ vertical columns. Monthly mean vertical columns generated with the above AMF and RSC algorithms are presented in Fig. 7 for August 2007.

A single GOME-2 scan packet contains 32 scans (assuming no post-processing filtering by SZA or CF), consisting of 24 high resolution front (forward sweep of instrument operation, measuring $80 \times 40 \mathrm{~km}^{2}$ ) and 8 back scans (wide scans obtained in the rapid back sweep to the scan start position, measuring $240 \times 40 \mathrm{~km}^{2}$ ). Here, the front scans are further divided into east, centre and west components, consisting of 8 scans each, allowing investigation into the effect of the GOME-2 scan bias on the reference sector method (RSM), and final vertical columns. Figure 8 and Table 3 show that by incorporating all scans into the correction, directional scan bias averages out over the swath, whilst including only east or west scans imparts a clear bias on the subtractive polynomial according to scan direction applied. Nevertheless, the scan bias correction remains essential, with error at swath edges likely to propagate through monthly and seasonal means.
Table 3. Monthly mean $\mathrm{CH}_{2} \mathrm{O}$ vertical columns for August 2007 (units of $\times 10^{16}$ molecules $\mathrm{cm}^{-2}$ ) derived from usage of unique directional swath components for the reference sector correction, taking the reference retrieval as source data.

\begin{tabular}{lcccc}
\hline Scans & Global & AMA & SEUS & PAC \\
\hline All & 0.49 & 1.62 & 2.02 & 0.31 \\
Back & 0.45 & 1.58 & 1.98 & 0.28 \\
Front & 0.49 & 1.63 & 2.02 & 0.31 \\
Centre & 0.30 & 1.36 & 1.73 & 0.12 \\
East & 0.54 & 1.83 & 2.23 & 0.46 \\
West & 0.30 & 1.36 & 1.73 & 0.12 \\
\hline
\end{tabular}

\subsection{Homogenisation of $\mathrm{CH}_{2} \mathrm{O}$ vertical columns}

To test the effect of the application of the reference sector correction on the $\mathrm{CH}_{2} \mathrm{O}$ retrieval, differences in $\mathrm{CH}_{2} \mathrm{O}$ slant columns are compared with their corresponding vertical columns for all tests. Selected $\mathrm{CH}_{2} \mathrm{O}$ vertical column results are summarised in Table 4 . This demonstrates major reductions in differences between test retrievals and the reference retrieval, particularly so for tests with previously very large differences, bringing all global vertical column differences within $21 \%$ of the reference, compared to a maximum slant column difference of $-390 \%$.

Despite widely varying errors in terms of fit residuals between retrievals, Table 5 demonstrates that application of the reference sector correction apparently causes previously disparate retrievals to converge around a broadly similar set of results. This ranges from those tests with small effects on global slant column mean (such as test $3 \mathrm{~g}-\mathrm{I}_{0}$ correcting all absorbers, with previous slant column differences on the reference retrieval of $0.03 \%$ converting to $1.69 \%$ in vertical columns), to those with the largest effects (test $2 \mathrm{c}-$ fitting in the original GOME- $1 \mathrm{CH}_{2} \mathrm{O}$ retrieval window whose global slant column difference of $-390 \%$ is reduced to just $-21 \%$ ). Of note, tests $2 \mathrm{a}, 2 \mathrm{c}, 4 \mathrm{a}$ and $5 \mathrm{a}$ stand out due to the much smaller relative differences when vertical columns are considered instead of slant columns. Based on the PAC study site, the vast majority of this variability can be attributed to retrievals at or around the limit of $\mathrm{CH}_{2} \mathrm{O}$ detection. Ocean retrievals typically return very low $\mathrm{CH}_{2} \mathrm{O}$ slant column values, with its production determined only by $\mathrm{CH}_{4}$ oxidation rather than the spatially limited enhanced continental isoprene sources. This homogenisation effect on the $\mathrm{CH}_{2} \mathrm{O}$ vertical columns occurs because once the slant column bias over the Pacific Ocean is subtracted, subsequent corrected slant columns are at or close to zero. Addition of a common GEOS-Chem model $\mathrm{CH}_{2} \mathrm{O}$ background therefore simply results in $\mathrm{CH}_{2} \mathrm{O}$ vertical columns of similar magnitude (irrespective of the spectral fitting procedure). However, whilst the reference sector method adjusts $\mathrm{CH}_{2} \mathrm{O}$ VCs to within similar orders of magnitude, it should be noted that the overall effect is to correct for a global offset, and 
Table 4. Summary of mean vertical columns (units of $\times 10^{16}$ molecules $\mathrm{cm}^{-2}$ ) for selected tests, the range of which are in sharp contrast to the variability found with the SC precursors (a full table of results is available from the authors).

\begin{tabular}{lcccccccc}
\hline & \multicolumn{2}{c}{ Global } & \multicolumn{2}{c}{ AMA } & \multicolumn{2}{c}{ SEUS } & \multicolumn{2}{c}{ PAC } \\
Fit window (nm) & Mean & $\pm 1 \sigma$ & Mean & $\pm 1 \sigma$ & Mean & $\pm 1 \sigma$ & Mean & $\pm 1 \sigma$ \\
\hline Reference retrieval & 0.49 & 0.43 & 1.62 & 0.35 & 2.02 & 0.44 & 0.31 & 0.11 \\
\hline Spectral range & & & & & & & & \\
BrO window & & & & & & & & \\
1a. 332-359 & 0.50 & 0.43 & 1.57 & 0.36 & 2.03 & 0.44 & 0.32 & 0.11 \\
1b. 332-359 (+ OClO) & 0.48 & 0.42 & 1.56 & 0.36 & 1.98 & 0.44 & 0.31 & 0.12 \\
CH $H_{2}$ - window & & & & & & & & \\
2a. 325.5-350 & 0.57 & 0.48 & 1.54 & 0.31 & 2.05 & 0.44 & 0.30 & 0.10 \\
2b. 332-350 & 0.49 & 0.44 & 1.70 & 0.40 & 2.07 & 0.46 & 0.33 & 0.11 \\
2c. 337.5-359 & 0.39 & 0.56 & 1.76 & 0.49 & 1.98 & 0.52 & 0.28 & 0.13 \\
2d. 327.5-356.6 & 0.51 & 0.48 & 1.52 & 0.32 & 1.89 & 0.45 & 0.27 & 0.09 \\
\hline Absorber effects & & & & & & & & \\
3b. O & & & & & & & & \\
3e. OClO & 0.41 & 0.41 & 1.57 & 0.37 & 1.84 & 0.43 & 0.28 & 0.11 \\
3g. I0 correct all abs. & 0.51 & 0.47 & 1.71 & 0.37 & 2.12 & 0.48 & 0.33 & 0.11 \\
\hline Polynomial degree & 0.49 & 0.42 & 1.61 & 0.34 & 2.00 & 0.44 & 0.32 & 0.11 \\
4a. 4th order polynomial & 0.55 & 0.47 & 1.65 & 0.32 & 2.06 & 0.46 & 0.31 & 0.10 \\
4b. 3rd order polynomial & 0.58 & 0.51 & 1.62 & 0.32 & 2.11 & 0.47 & 0.31 & 0.11 \\
\hline Instrument corrections & & & & & & & & \\
5a. No scan bias correction & 0.52 & 0.43 & 1.61 & 0.34 & 1.98 & 0.44 & 0.32 & 0.10 \\
5b. No undersampling & 0.52 & 0.44 & 1.64 & 0.35 & 2.07 & 0.45 & 0.32 & 0.11 \\
\hline
\end{tabular}

Table 5. Summary of the reference sector correction on the retrieved $\mathrm{CH}_{2} \mathrm{O}$ vertical columns relative to the default reference retrieval (i.e. $\triangle \mathrm{VC})$. The slant column differences $(\triangle \mathrm{SC})$ from each test are also shown for comparison. Differences are in $\%$.

\begin{tabular}{|c|c|c|c|c|c|c|c|c|}
\hline \multirow[b]{2}{*}{ Test } & \multicolumn{2}{|c|}{ Global } & \multicolumn{2}{|c|}{ AMA } & \multicolumn{2}{|c|}{ SEUS } & \multicolumn{2}{|c|}{ PAC } \\
\hline & $\Delta \mathrm{SC}$ & $\Delta \mathrm{VC}$ & $\Delta \mathrm{SC}$ & $\Delta \mathrm{VC}$ & $\Delta \mathrm{SC}$ & $\Delta \mathrm{VC}$ & $\Delta \mathrm{SC}$ & $\Delta \mathrm{VC}$ \\
\hline \multicolumn{9}{|l|}{ Spectral range $(\mathrm{nm})$} \\
\hline \multicolumn{9}{|l|}{$\mathrm{BrO}$ window } \\
\hline 1a. $332-359$ & 21 & 1 & 0 & -3 & 6 & 1 & 17 & 2 \\
\hline 1b. $332-359(+\mathrm{OClO})$ & 49 & -2 & 8 & -4 & 12 & -2 & 40 & -0 \\
\hline \multicolumn{9}{|l|}{$\mathrm{CH}_{2} \mathrm{O}$ window } \\
\hline 2a. $325.5-350$ & 190 & 16 & 35 & -5 & 44 & 2 & 121 & -2 \\
\hline 2b. $332-350$ & -27 & -1 & -2 & 5 & -4 & 3 & -16 & 7 \\
\hline 2c. 337.5-359 & -390 & -21 & -98 & 8 & -97 & -2 & -328 & -9 \\
\hline 2d. 327.5-356.6 & -17 & 3 & -26 & -6 & -14 & -6 & -60 & -14 \\
\hline \multicolumn{9}{|l|}{ Absorber effects } \\
\hline 3b. $\mathrm{O}_{4}$ & -46 & 17 & 11 & 3 & 6 & 9 & -38 & 8 \\
\hline 3e. $\mathrm{OClO}$ & 32 & -4 & -9 & -6 & -7 & -5 & 45 & -5 \\
\hline 3g. $\mathrm{I}_{0}$ correct all abs. & 0 & 2 & 1 & 1 & -3 & 1 & -8 & -2 \\
\hline \multicolumn{9}{|l|}{ Polynomial degree } \\
\hline 4a. 4 th order polynomial & -105 & -11 & 23 & -2 & 27 & -2 & -60 & 0 \\
\hline 4b. 3rd order polynomial & 16 & -17 & -11 & 0 & 8 & -5 & 28 & 0 \\
\hline \multicolumn{9}{|l|}{ Instrument corrections } \\
\hline 5a. No scan bias correction & 133 & 5 & 32 & 1 & 30 & 2 & 99 & 3 \\
\hline 5b. No undersampling & 45 & 5 & 4 & 1 & 14 & 3 & 13 & 5 \\
\hline
\end{tabular}




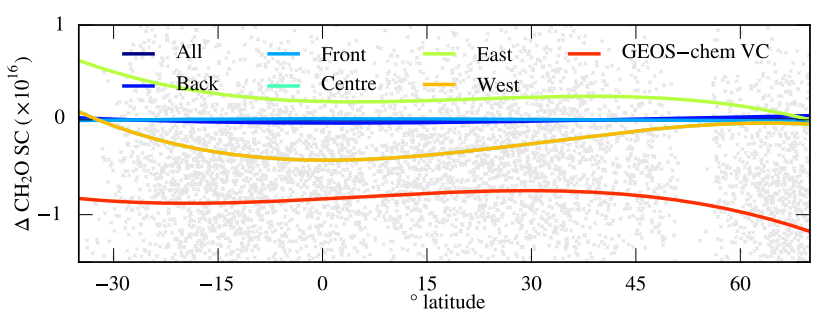

Fig. 8. Reference sector correction for the 9 August 2007. Grey markers indicate retrieved slant column values in the reference strip from which we model our subtractive polynomial. Solid lines represent the polynomial taken from these values according to scan position. Note large differences between east and west swath corrections, illustrating bias present in retrievals according to swath position. "All" is obscured by "Back" and "Front", whilst "Centre" is obscured by "West".

latitudinal variation caused by spectral interference with ancillary absorbers at high latitudes. By not discriminating spatially, the technique maintains compatibility and comparability between the various retrievals.

\subsection{Cloud screen testing}

Scans with an effective cloud fraction of $>0.4$ are initially excluded from analysis. Here, the effect of increasing and decreasing the CF threshold for the reference retrieval is specifically examined. The high spatial sampling frequency of GOME-2 provides the opportunity to test a higher rejection rate on cloudy pixels for lower cloud fractions. This will yield less variability in monthly slant column means due to the reduction in the number of observations, for which the fits are artificially adjusted due to cloud scattering and absorption effects.

Figure 9 shows the effect this cloud fraction adjustment has on the monthly $\mathrm{CH}_{2} \mathrm{O}$ slant columns and scan counts. A cloud fraction of 0.4 , used as the reference threshold, is seen to offer a reasonable compromise between elimination of cloudy pixels without significantly affecting slant column values. This is further illustrated in Fig. 10, particularly for the AMA study site, where the majority of cloud can be seen to be sitting in the $300-600 \mathrm{hPa}$ region. $\mathrm{CH}_{2} \mathrm{O}$ slant and vertical columns for the PAC region are stable above a cloud fraction limit of 0.1 , whilst minor correlations between increasing scan counts and vertical columns are noted for the AMA region. This situation is mirrored, albeit with a lower intensity, for the SEUS region, whose slant and vertical column values increase sharply in parallel with lower cloud fraction limits. The vertical column is seen to increase in parallel with an increased cloud cover at $\mathrm{CF}>0.4$, which is not noted for the corresponding slant columns. Whilst this offers a useful indicator of an appropriate $\mathrm{CF}$ threshold, it also shows the AMF is providing a sub-optimal conversion value for such scans due to an unrealistic interpretation of radiation transfer above, within, and below clouds.

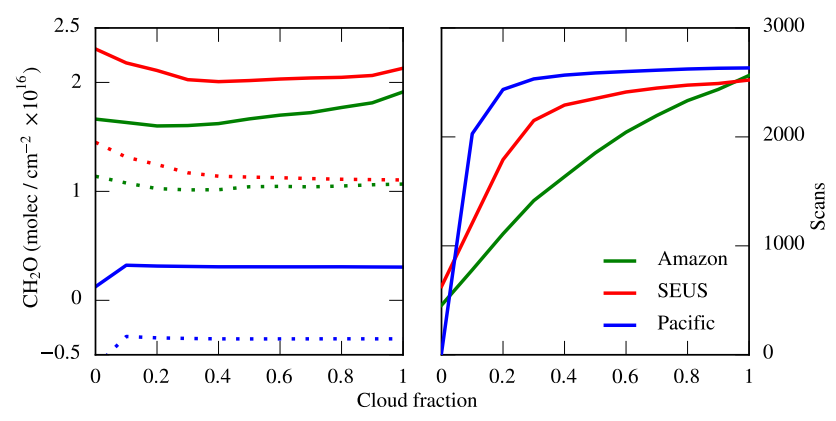

Fig. 9. Altering the cloud fraction threshold from our reference retrieval shows the wide range of $\mathrm{CH}_{2} \mathrm{O}$ slant columns (left hand plot, dotted lines), vertical columns (left hand plot, solid lines), and scan counts (right hand plot) taken into monthly means for the three detailed study sites. A cloud fraction $(\mathrm{CF})$ of 1 indicates all scans are taken into account.

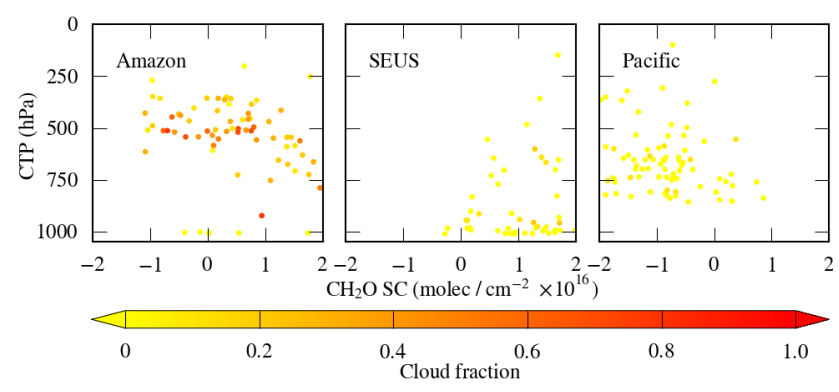

Fig. 10. $\mathrm{CH}_{2} \mathrm{O}$ SC against cloud top pressure (CTP), with cloud fractions from $0-1.0$ denoted by colour, for the three study sites on the 9 August 2007. The Amazon site shows the large number of high $\mathrm{CF}$ scans $(\mathrm{CF}>0.4)$ expected in the region due to the regional climate, the majority of which are in the $300-600 \mathrm{hPa}$ region, whilst the southeastern US and Pacific Ocean regions display no clear correlation between $\mathrm{CF}$ and $\mathrm{CTP}$.

Interaction between cloud and aerosol which exist over the study regions, and their representation by the AMF, may play a large part in spurious slant to vertical column conversions above certain cloud thresholds (Boersma et al., 2004). Biomass burning, often encountered in tropical ecosystems such as the Amazon, encourages pyroconvection, with associated uplift of aerosol high into the troposphere $(\sim 5 \mathrm{~km})$ (Gonzi and Palmer, 2010). Aerosol at these heights can act to shield incoming radiation from underlying $\mathrm{CH}_{2} \mathrm{O}$, effecting a decrease in the AMF and subsequent increase in $\mathrm{CH}_{2} \mathrm{O}$ vertical columns. High clouds also affect the AMF in the same way, but possibly to a greater extent owing to their increased albedo compared to aerosols. Considering biomass burning cases, these two processes are likely to act in concert, with a greater number of aerosol molecules providing cloud formation nuclei. 


\section{Conclusions}

This work presents an in-depth analysis of the parameters governing the accuracy and efficacy of GOME-2 DOAS $\mathrm{CH}_{2} \mathrm{O}$ retrievals. Testing has shown the major parameter influencing the minimisation of fitting residuals for $\mathrm{CH}_{2} \mathrm{O}$ fitting to be the spectral fit window, adjustment of which is shown to produce changes in retrieved slant column between 190 and $-390 \%$ globally. Polynomial order, $\mathrm{I}_{0}$ correction, fitted ancillary absorbers and offset corrections also have an significant impact on the fit residual. Subtle effects on fit quality and $\mathrm{CH}_{2} \mathrm{O}$ slant column are also noted with instrumental corrections, such as wavelength calibration, undersampling and scan bias correction, although these should be probably weighted with a similarly high importance, since the $\mathrm{CH}_{2} \mathrm{O}$ retrieval is close to the limits of the instrument's sensitivity. Reference fit settings (Table 1) are found to provide an optimal group of parameters for global $\mathrm{CH}_{2} \mathrm{O}$ retrievals, based on the minimisation of error each setting is seen to provide in contrast to viable alternatives.

Vertical columns are much less sensitive to the input fitting parameters than their slant columns, primarily due to application of the RSM technique. Analysis has shown that regardless of spectral fitting parameters, which often result in large slant column differences, addition of model $\mathrm{CH}_{2} \mathrm{O}$ background columns to the bias corrected slant columns allows convergence of the final GOME-2 vertical column product to within a range of 16 to $-21 \%$ globally for the various $\mathrm{CH}_{2} \mathrm{O}$ fitting windows. Cloud fraction is shown to have a large effect on both the monthly mean slant and vertical columns, the latter being affected by the relationship between the observed cloud top pressure and the $\mathrm{CH}_{2} \mathrm{O}$ vertical distribution.

Acknowledgements. This work was supported by the UK National Centre for Earth Observation (NCEO) and the UK Natural Environment Research Council (NERC) (grants NE/GE013810/2 and NE/D001471). GOME-2 data was provided by the British Atmospheric Data Centre courtesy of EUMETSAT. Georgina Miles and Richard Siddans at The Rutherford Appleton Laboratory assisted with cross section convolution, whilst Marco Vountas and Vladimir Rozanov at The Institute of Environmental Physics, University of Bremen, assisted with initial Ring spectra generation. The authors would also like to extend their special gratitude to Caroline Fayt at BIRA, acknowledging her continued support and generous assistance with the QDOAS analysis package.

Edited by: J. Tamminen

\section{References}

Abbot, D. S., Palmer, P. I., Martin, R. V., Chance, K. V., Jacob, D. J., and Guenther, A.: Seasonal and interannual variability of North American isoprene emissions as determined by formaldehyde column measurements from space, Geophys. Res. Lett., 30, 5-1-5-4, doi:10.1029/2003GL017336, 2003.

Aliwell, S. R., Van Roozendael, M., Johnston, P. V., Richter, A., Wagner, T., Arlander, D. W., Burrows, J. P., Fish, D. J., Jones, R. L., Tørnkvist, K. K., Lambert, J., Pfeilsticker, K., and Pundt, I.: Analysis for $\mathrm{BrO}$ in zenith-sky spectra: An intercomparison exercise for analysis improvement, J. Geophys. Res., 107, 10-110-20, doi:10.1029/2001JD000329, 2002.

Antón, M., Loyola, D., López, M., Vilaplana, J. M., Bañón, M., Zimmer, W., and Serrano, A.: Comparison of GOME2/MetOp total ozone data with Brewer spectroradiometer data over the Iberian Peninsula, Ann. Geophys., 27, 1377-1386, doi:10.5194/angeo-27-1377-2009, 2009.

Balis, D., Koukouli, M., Loyola, D., Valks, P., and Hao, N.: Second validation report of GOME-2 total ozone products (OTO/O3, NTO/O3) processed with GDP4.2, Report SAF/O3M/AUTH/GOME-2VAL/RP/02, O3M-SAF, 2008.

Barkley, M. P., Palmer, P. I., Kuhn, U., Kesselmeier, J., Chance, K., Kurosu, T. P., Martin, R. V., Helmig, D., and Guenther, A.: Net ecosystem fluxes of isoprene over tropical South America inferred from Global Ozone Monitoring Experiment (GOME) observations of HCHO columns, J. Geophys. Res., 113, D20304, doi:10.1029/2008JD009863, 2008.

Barkley, M. P., Palmer, P. I., De Smedt, I., Karl, T., Guenther, A., and Van Roozendael, M.: Regulated large-scale annual shutdown of Amazonian isoprene emissions?, Geophys. Res. Lett., 36, L04803, doi:10.1029/2008GL036843, 2009.

Barkley, M. P., Kurosu, T. P., Chance, K., De Smedt, I., Van Roozendael, M., Arneth, A., Hagberg, D., and Guenther, A.: Assessing sources of uncertainty in formaldehyde air mass factors over tropical South America: Implications for top-down isoprene emission estimates, J. Geophys. Res., 117, D13304, doi:10.1029/2011JD016827, 2012.

Barkley, M. P., De Smedt, I., Van Roozendael, M., Kurosu, T. P., Chance, K., Arneth, A., Hagberg, D., Guenther, A., Paulot, F., Marais, E., and Mao, J.: Top-down isoprene emissions over tropical South America inferred from SCIAMACHY and OMI formaldehyde columns, J. Geophys. Res., in press, 2013.

Boeke, N. L., Marshall, J. D., Alvarez, S., Chance, K. V., Fried, A., Kurosu, T. P., Rappenglück, B., Richter, D., Walega, J., Weibring, P., and Millet, D. B.: Formaldehyde columns from the Ozone Monitoring Instrument: Urban versus background levels and evaluation using aircraft data and a global model, J. Geophys. Res., 116, D05303, doi:10.1029/2010JD014870, 2011.

Boersma, K. F., Eskes, H. J., and Brinksma, E. J.: Error analysis for tropospheric $\mathrm{NO}_{2}$ retrieval from space, J. Geophys. Res., 109, D04311 1-20, doi:10.1029/2003JD003962, 2004.

Bogumil, K., Orphal, J., Homann, T., Voigt, S., Spietz, P., Fleischmann, O., Vogel, A., Hartmann, M., Kromminga, H., Bovensmann, H., Frerick, J., and Burrows, J.: Measurements of molecular absorption spectra with the SCIAMACHY pre-flight model: instrument characterization and reference data for atmospheric remote-sensing in the $230-2380 \mathrm{~nm}$ region, J. Photoch. Photobio. A-Chemistry, 157, 167-184, doi:10.1016/S10106030(03)00062-5, 2003. 
Brauers, T., Bossmeyer, J., Dorn, H.-P., Schlosser, E., Tillmann, R., Wegener, R., and Wahner, A.: Investigation of the formaldehyde differential absorption cross section at high and low spectral resolution in the simulation chamber SAPHIR, Atmos. Chem. Phys., 7, 3579-3586, doi:10.5194/acp-7-3579-2007, 2007.

Buchwitz, M., Rozanov, V. V., and Burrows, J. P.: A near-infrared optimized DOAS method for the fast global retrieval of atmospheric $\mathrm{CH}_{4}, \mathrm{CO}, \mathrm{CO}_{2}, \mathrm{H}_{2} \mathrm{O}$, and $\mathrm{N}_{2} \mathrm{O}$ total column amounts from SCIAMACHY Envisat-1 nadir radiances, J. Geophys. Res., 105, 15231-15245, 2000.

Burrows, J. P., Weber, M., Buchwitz, M., Rozanov, V., LadstätterWeißenmayer, A., Richter, A., Debeek, R., Hoogen, R., Bramstedt, K., Eichmann, K., Eisinger, M., and Perner, D.: The Global Ozone Monitoring Experiment (GOME): Mission concept and first scientific results, J. Atmos. Sci., 56, 151-175, 1999.

Cai, Z., Liu, Y., Liu, X., Chance, K., Nowlan, C. R., Lang, R., Munro, R., and Suleiman, R.: Characterization and correction of Global Ozone Monitoring Experiment 2 ultraviolet measurements and application to ozone profile retrievals, J. Geophys. Res., 117, D07305, doi:10.1029/2011JD017096, 2012.

Caspar, C. and Chance, K.: GOME wavelength calibration using solar and atmospheric spectra, European Space Agency, (Special Publication) ESA SP, 609-612, 1997.

Chance, K.: OMI Trace Gas Algorithms, OMI Algorithm Theoretical Basis Document, Smithsonian Astrophysical Observatory, Cambridge, MA, USA, 2002.

Chance, K. and Spurr, R. J. D.: Ring effect studies: Rayleigh scattering, including molecular parameters for rotational Raman scattering, and the Fraunhofer spectrum, Appl. Optics, 36, 52245230, doi:10.1364/AO.36.005224, 1997.

Chance, K., Palmer, P. I., Spurr, R. J. D., Martin, R. V., Kurosu, T. P., and Jacob, D. J.: Satellite observations of formaldehyde over North America from GOME, Geophys. Res. Lett., 27, 34613464, 2000.

Chance, K., Kurosu, T. P., and Sioris, C. E.: Undersampling correction for array detector-based satellite spectrometers, Appl. Optics, 44, 1296-1304, doi:10.1364/AO.44.001296, 2005.

Coldewey-Egbers, M., Weber, M., Lamsal, L. N., de Beek, R., Buchwitz, M., and Burrows, J. P.: Total ozone retrieval from GOME UV spectral data using the weighting function DOAS approach, Atmos. Chem. Phys., 5, 1015-1025, doi:10.5194/acp5-1015-2005, 2005.

Cooke, M. C., Utembe, S. R., Gorrotxategi Carbajo, P., Archibald, A. T., Orr-Ewing, A. J., Jenkin, M. E., Derwent, R. G., Lary, D. J., and Shallcross, D. E.: Impacts of formaldehyde photolysis rates on tropospheric chemistry, Atmos. Sci. Lett., 11, 33-38, doi:10.1002/asl.251, 2010.

Curci, G., Palmer, P. I., Kurosu, T. P., Chance, K., and Visconti, G.: Estimating European volatile organic compound emissions using satellite observations of formaldehyde from the Ozone Monitoring Instrument, Atmos. Chem. Phys., 10, 11501-11517, doi:10.5194/acp-10-11501-2010, 2010.

De Smedt, I.: Long-Term Global Observations of Tropospheric Formaldehyde Retrieved from Spaceborne Nadir UV Sensors, Ph.D. thesis, Universite Libre De Bruxelles, Laboratoire do Chimie Quantique et Photophysique, Faculté de Sciences Appliquées, 2011.

De Smedt, I., Müller, J.-F., Stavrakou, T., van der A, R., Eskes, H., and Van Roozendael, M.: Twelve years of global obser- vations of formaldehyde in the troposphere using GOME and SCIAMACHY sensors, Atmos. Chem. Phys., 8, 4947-4963, doi:10.5194/acp-8-4947-2008, 2008.

De Smedt, I., Stavrakou, J., Müller, J.-F., Hao, N., Valks, P., Loyola, D., and Van Roozendael, M.: $\mathrm{H}_{2} \mathrm{CO}$ Columns Retrieved From GOME-2: First Scientific Results And Progress Towards The Development Of An Operational Product, in: Proceedings of the EUTMETSAT conference, 2009.

De Smedt, I., Stavrakou, T., Müller, J.-F., Van Der A, R. J., and Van Roozendael, M.: Trend detection in satellite observations of formaldehyde tropospheric columns, Geophys. Res. Lett., 37, L18808, doi:10.1029/2010GL044245, 2010.

De Smedt, I., Van Roozendael, M., Stavrakou, T., Müller, J.-F., Lerot, C., Theys, N., Valks, P., Hao, N., and van der A, R.: Improved retrieval of global tropospheric formaldehyde columns from GOME-2/MetOp-A addressing noise reduction and instrumental degradation issues, Atmos. Meas. Tech., 5, 2933-2949, doi:10.5194/amt-5-2933-2012, 2012.

EUMETSAT: GOME-2 Product Generation Statement, Tech. Rep. EPS.SYS.SPE.990011, Eumetsat, 2011.

Fayt, C., De Smedt, I., Letocart, V., Merlaud, A., Pinardi, G., and Van Roozendael, M.: QDOAS software user manual, Belgian Institute for Space Aeronomy, 1st Edn., 2011.

Fleischmann, O. C., Hartmann, M., Burrows, J. P., and Orphal, J.: New ultraviolet absorption cross-sections of $\mathrm{BrO}$ at atmospheric temperatures measured by time-windowing Fourier transform spectroscopy, J. Photoch. Photobiol. A-Chemistry, 168, 117-132, doi:10.1016/j.jphotochem.2004.03.026, 2004.

Fried, A., Walega, J. G., Olson, J. R., Crawford, J. H., Chen, G., Weibring, P., Richter, D., Roller, C., Tittel, F. K., Heikes, B. G., Snow, J. A., Shen, H., O’Sullivan, D. W., Porter, M., Fuelberg, H., Halland, J., and Millet, D. B.: Formaldehyde over North America and the North Atlantic during the summer 2004 INTEX campaign: Methods, observed distributions, and measurement-model comparisons, J. Geophys. Res., 113, doi:10.1029/2007JD009185, 2008.

Fu, T. ., Jacob, D. J., Palmer, P. I., Chance, K., Wang, Y. X., Barletta, B., Blake, D. R., Stanton, J. C., and Pilling, M. J.: Space-based formaldehyde measurements as constrains on volatile organic compound emissions in east and south Asia and implications for ozone, J. Geophys. Res., 112, D06312, doi:10.1029/2006JD007853, 2007.

Gonzi, S. and Palmer, P. I.: Vertical transport of surface fire emissions observed from space, J. Geophys. Res., 115, D02306, doi:10.1029/2009JD012053, 2010.

Gonzi, S., Palmer, P. I., Barkley, M. P., De Smedt, I., and Van Roozendael, M.: Biomass burning emission estimates inferred from satellite column measurements of HCHO: Sensitivity to co-emitted aerosol and injection height, Geophys. Res. Lett., 38, L14807, doi:10.1029/2011GL047890, 2011.

Greenblatt, G. D., Orlando, J. J., Burkholder, J. B., and Ravishankara, A. R.: Absorption measurements of oxygen between 330 and $1140 \mathrm{~nm}$, J. Geophys. Res., 95, 18577-18582, doi:10.1029/JD095iD11p18577, 1990.

Herman, J. R. and Celarier, E. A.: Earth surface reflectivity climatology at 340-380 nm from TOMS data, J. Geophys. Res., 102, 28003-28011, doi:10.1029/97JD02074, 1997.

Kühl, S., Wilms-Grabe, W., Frankenberg, C., Grzegorski, M., Platt, U., and Wagner, T.: Comparison of $\mathrm{OClO}$ nadir measurements 
from SCIAMACHY and GOME, Adv. Space Res., 37, 22472253, doi:10.1016/j.asr.2005.06.061, 2006.

Kurosu, T. P., Chance, K., and Sioris, C. E.: Preliminary results for $\mathrm{HCHO}$ and $\mathrm{BrO}$ from the EOS-aura ozone monitoring instrument, in: Proceedings of SPIE - The International Society for Optical Engineering, 5652, 116-123, 2004.

Lee, C., Richter, A., Weber, M., and Burrows, J. P.: $\mathrm{SO}_{2}$ Retrieval from SCIAMACHY using the Weighting Function DOAS (WFDOAS) technique: comparison with Standard DOAS retrieval, Atmos. Chem. Phys., 8, 6137-6145, doi:10.5194/acp-8-61372008, 2008.

Liu, X., Chance, K., Sioris, C. E., and Kurosu, T. P.: Impact of using different ozone cross sections on ozone profile retrievals from Global Ozone Monitoring Experiment (GOME) ultraviolet measurements, Atmos. Chem. Phys., 7, 3571-3578, doi:10.5194/acp7-3571-2007, 2007.

Loyola, D., Valks, P., Hao, N., Rix, M., and Slijkhuis, S.: Algorithm Theoretical Basis Document for GOME-2 Total Column Products of Ozone, $\mathrm{NO}_{2}$, tropospheric $\mathrm{NO}_{2}, \mathrm{BrO}, \mathrm{SO}_{2}, \mathrm{H}_{2} \mathrm{O}$, $\mathrm{HCHO}, \mathrm{OClO}$ and Cloud Properties, Tech. Rep. DLR/GOME2/ATBD/01, Eumetsat, 2011a.

Loyola, D. G., Koukouli, M. E., Valks, P., Balis, D. S., Hao, N., Van Roozendael, M., Spurr, R. J. D., Zimmer, W., Kiemle, S., Lerot, C., and Lambert, J. C.: The GOME-2 total column ozone product: Retrieval algorithm and ground-based validation, J. Geophys. Res., 116, D07302, doi:10.1029/2010JD014675, 2011 b.

MacDonald, S. M., Oetjen, H., Mahajan, A. S., Whalley, L. K., Edwards, P. M., Heard, D. E., Jones, C. E., and Plane, J. M. C.: DOAS measurements of formaldehyde and glyoxal above a south-east Asian tropical rainforest, Atmos. Chem. Phys., 12, 5949-5962, doi:10.5194/acp-12-5949-2012, 2012.

Malicet, J., Daumont, D., Charbonnier, J., Parisse, C., Chakir, A., and Brion, J.: Ozone UV spectroscopy. II. Absorption crosssections and temperature dependence, J. Atmos. Chem., 21, 263273, doi:10.1007/BF00696758, 1995.

Marais, E. A., Jacob, D. J., Kurosu, T. P., Chance, K., Murphy, J. G., Reeves, C., Mills, G., Casadio, S., Millet, D. B., Barkley, M. P., Paulot, F., and Mao, J.: Isoprene emissions in Africa inferred from OMI observations of formaldehyde columns, Atmos. Chem. Phys., 12, 6219-6235, doi:10.5194/acp-12-62192012, 2012.

Marbach, T., Beirle, S., Penning de Vries, M., Liu, C., and Wagner, T.: Sources and trends of Tropospheric Formaldehyde (HCHO) Sources and trends of Tropospheric Formaldehdye (HCHO) derived from GOME-1 and -2, Living Planet Symposium, ESA, 2010.

Martin, R. V., Chance, K., Jacob, D. J., Kurosu, T. P., Spurr, R. J. D., Bucsela, E., Gleason, J. F., Palmer, P. I., Bey, I., Fiore, A. M., Li, Q., Yantosca, R. M., and Koelemeijer, R. B. A.: An improved retrieval of tropospheric nitrogen dioxide from GOME, J. Geophys. Res., 107, doi:10.1029/2001JD001027, 2002.

Meller, R. and Moortgat, G. K.: Temperature dependence of the absorption cross sections of formaldehyde between 223 and $323 \mathrm{~K}$ in the wavelength range $225-375 \mathrm{~nm}$, J. Geophys. Res., 105, 7089-7101, doi:10.1029/1999JD901074, 2000.

Millet, D. B., Jacob, D. J., Turquety, S., Hudman, R. C., Wu, S., Fried, A., Walega, J., Heikes, B. G., Blake, D. R., Singh, H. B., Andersen, B. E., and Clarke, A. D.: Formaldehyde distribu- tion over North America: Implications for satellite retrievals of formaldehyde columns and isoprene emission, J. Geophys. Res., 111, doi:10.1029/2005JD006853, 2006.

Millet, D. B., Jacob, D. J., Boersma, K. F., Fu, T., Kurosu, T. P., Chance, K., Heald, C. L., and Guenther, A.: Spatial distribution of isoprene emissions from North America derived from formaldehyde column measurements by the OMI satellite sensor, J. Geophys. Res., 113, D02307, doi:10.1029/2007JD008950, 2008.

Oetjen, H., Wittrock, F., Richter, A., Chipperfield, M. P., Medeke, T., Sheode, N., Sinnhuber, B.-M., Sinnhuber, M., and Burrows, J. P.: Evaluation of stratospheric chlorine chemistry for the Arctic spring 2005 using modelled and measured OClO column densities, Atmos. Chem. Phys., 11, 689-703, doi:10.5194/acp-11-6892011, 2011.

Palmer, P. I., Jacob, D. J., Chance, K., Martin, R. V., Spurr, R. J. D., Kurosu, T. P., Bey, I., Yantosca, R., Fiore, A., and Li, Q.: Air mass factor formulation for spectroscopic measurements from satellites: Application to formaldehyde retrievals from the Global Ozone Monitoring Experiment, J. Geophys. Res., 106, 1453914550, doi:10.1029/2000JD900772, 2001.

Palmer, P. I., Jacob, D. J., Fiore, A. M., Martin, R. V., Chance, K., and Kurosu, T. P.: Mapping isoprene emissions over North America using formaldehyde column observations from space, J. Geophys. Res., 108, 2-1-2-13, doi:10.1029/2002JD002153, 2003.

Palmer, P. I., Abbot, D. S., Fu, T., Jacob, D. J., Chance, K., Kurosu, T. P., Guenther, A., Wiedinmyer, C., Stanton, J. C., Pilling, M. J., Pressley, S. N., Lamb, B., and Sumner, A. L.: Quantifying the seasonal and interannual variability of North American isoprene emissions using satellite observations of the formaldehyde column, J. Geophys. Res., 111, D12315, doi:10.1029/2005JD006689, 2006.

Parrish, D. D., Ryerson, T. B., Mellqvist, J., Johansson, J., Fried, A., Richter, D., Walega, J. G., Washenfelder, R. A., de Gouw, J. A., Peischl, J., Aikin, K. C., McKeen, S. A., Frost, G. J., Fehsenfeld, F. C., and Herndon, S. C.: Primary and secondary sources of formaldehyde in urban atmospheres: Houston Texas region, Atmos. Chem. Phys., 12, 3273-3288, doi:10.5194/acp-12-32732012, 2012.

Richter, A. and Burrows, J. P.: Tropospheric $\mathrm{NO}_{2}$ from GOME measurements, Adv. Space Res., 29, 1673-1683, doi:10.1016/S02731177(02)00100-X, 2002.

Richter, A., Begoin, M., Hilboll, A., and Burrows, J. P.: An improved $\mathrm{NO}_{2}$ retrieval for the GOME-2 satellite instrument, Atmos. Meas. Tech., 4, 1147-1159, doi:10.5194/amt-4-1147-2011, 2011.

Rottenberger, S., Kuhn, U., Wolf, A., Schebeske, G., Oliva, S. T., Tavares, T. M., and Kesselmeier, J.: Exchange of short-chain aldehydes between Amazonian vegetation and the atmosphere, Ecol. Appl., 14, S247-S262, doi:10.1890/01-6027, 2004.

Rozanov, A., Rozanov, V., Buchwitz, M., Kokhanovsky, A., and Burrows, J. P.: SCIATRAN 2.0 - A new radiative transfer model for geophysical applications in the $175-2400 \mathrm{~nm}$ spectral region, Adv. Space Res., 36, 1015-1019, doi:10.1016/j.asr.2005.03.012, 2005.

Shim, C., Wang, Y., Choi, Y., Palmer, P. I., Abbot, D. S., and Chance, K.: Constraining global isoprene emissions with Global Ozone Monitoring Experiment (GOME) formaldehyde column measurements, J. Geophys. Res., 110, 1-14, 
doi:10.1029/2004JD005629, 2005.

Siddans, R., Kerridge, B., and Latter, B.: Analysis of GOME-2 Slit function Measurements, Executive Summary Eumetsat Contract No. EUM/CO/04/1298/RM, Rutherford Appleton Laboratory, 2006.

Singh, H. B., Kanakidou, M., Crutzen, P. J., and Jacob, D. J.: High concentrations and photochemical fate of oxygenated hydrocarbons in the global troposphere, Nature, 378, 50-54, doi:10.1038/378050a0, 1995.

Spurr, R. J. D., Kurosu, T. P., and Chance, K. V.: A linearized discrete ordinate radiative transfer model for atmospheric remote-sensing retrieval, J. Quant. Spectrosc. Ra., 68, 689-735, doi:10.1016/S0022-4073(00)00055-8, 2001.

Stavrakou, T., Müller, J.-F., De Smedt, I., Van Roozendael, M., van der Werf, G. R., Giglio, L., and Guenther, A.: Evaluating the performance of pyrogenic and biogenic emission inventories against one decade of space-based formaldehyde columns, Atmos. Chem. Phys., 9, 1037-1060, doi:10.5194/acp-9-1037-2009, 2009a.

Stavrakou, T., Müller, J.-F., De Smedt, I., Van Roozendael, M., van der Werf, G. R., Giglio, L., and Guenther, A.: Global emissions of non-methane hydrocarbons deduced from SCIAMACHY formaldehyde columns through 2003-2006, Atmos. Chem. Phys., 9, 3663-3679, doi:10.5194/acp-9-3663-2009, 2009b.

Theys, N.: Atmospheric Bromine Monoxide: multi-platform observations and model calculations, Universite Libre De Bruxelles, Laboratoire do Chimie Quantique et Photophysique, Faculté de Sciences Appliquées, 2010.

Theys, N., Van Roozendael, M., Hendrick, F., Yang, X., De Smedt, I., Richter, A., Begoin, M., Errera, Q., Johnston, P. V., Kreher, K., and De Mazière, M.: Global observations of tropospheric BrO columns using GOME-2 satellite data, Atmos. Chem. Phys., 11, 1791-1811, doi:10.5194/acp-11-1791-2011, 2011.

Thomas, W., Hegels, E., Slijkhuis, S., Spurr, R., and Chance, K.: Detection of biomass burning combustion products in Southeast Asia from backscatter data taken by the GOME spectrometer, Geophys. Res. Lett., 25, 1317-1320, doi:10.1029/98GL01087, 1998.

Valks, P., Pinardi, G., Richter, A., Lambert, J.-C., Hao, N., Loyola, D., Van Roozendael, M., and Emmadi, S.: Operational total and tropospheric $\mathrm{NO}_{2}$ column retrieval for GOME-2, Atmos. Meas. Tech., 4, 1491-1514, doi:10.5194/amt-4-1491-2011, 2011.
Van Geffen, J. H. G. M. and Van Oss, R. F.: Wavelength calibration of spectra measured by the Global Ozone Monitoring Experiment by use of a high-resolution reference spectrum, Appl. Optics, 42, 2739-2753, doi:10.1364/AO.42.002739, 2003.

Van Roozendael, M., Soebijanta, V., Fayt, C., and Lambert, J.-C.: Investigation of DOAS issues affecting the accuracy of the GDP version 3.0 total ozone product, Tech. rep., Space Aeronomy Institute of Belgium, 2002.

Vandaele, A. C., Hermans, C., Simon, P. C., Carleer, M., Colin, R., Fally, S., Mérienne, M. F., Jenouvrier, A., and Coquart, B.: Measurements of the $\mathrm{NO}_{2}$ absorption cross-section from $42000 \mathrm{~cm}^{-1}$ to $10000 \mathrm{~cm}^{-1}(238-1000 \mathrm{~nm})$ at $220 \mathrm{~K}$ and 294 K, J. Quant. Spectrosc. Ra., 59, 171-184, 1998.

Vountas, M., Rozanov, V. V., and Burrows, J. P.: Ring effect: Impact of rotational Raman scattering on radiative transfer in earth's atmosphere, J. Quant. Spectrosc. Ra., 60, 943-961, doi:10.1016/S0022-4073(97)00186-6, 1998.

Vrekoussis, M., Wittrock, F., Richter, A., and Burrows, J. P.: GOME-2 observations of oxygenated VOCs: what can we learn from the ratio glyoxal to formaldehyde on a global scale?, Atmos. Chem. Phys., 10, 10145-10160, doi:10.5194/acp-1010145-2010, 2010.

Wang, P., Stammes, P., van der A, R., Pinardi, G., and van Roozendael, M.: FRESCO+: an improved $\mathrm{O}_{2}$ A-band cloud retrieval algorithm for tropospheric trace gas retrievals, Atmos. Chem. Phys., 8, 6565-6576, doi:10.5194/acp-8-6565-2008, 2008.

Wittrock, F.: The retrieval of oxygenated volatile organic compounds by remote sensing techniques, Ph.D. thesis, Universität Bremen, 2006.

Wittrock, F., Richter, A., Ladstäter-Weißenmayer, A., and Burrows, J. P.: Global observations of formaldehyde, in: European Space Agency, (Special Publication) ESA SP, 1358-1362, 2000.

Yokelson, R. J.: Emissions of formaldehyde, acetic acid, methanol, and other trace gases from biomass fires in North Carolina measured by airborne Fourier transform infrared spectroscopy, J. Geophys. Res., 104, 30109-30125, 1999. 